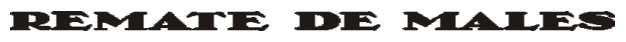

Campinas-SP, v.38, n.2, pp. 919-959, jul./dez. 2018

\title{
INDÍGENAS EM MOVIMENTO. LITERATURA COMO ATIVISMO
}

\author{
Leno Francisco Danner ${ }^{1}$ \\ Julie Dorrico² \\ Fernando Danner ${ }^{3}$
}

Resumo: Neste artigo, correlacionamos o desenvolvimento e o protagonismo público-políticos do Movimento Indígena brasileiro, a partir de meados de 1970, com a emergência e a consolidação da literatura indígena brasileira, a partir de 1990. Argumentaremos que, assim como as lideranças e os intelectuais indígenas fundadores do Movimento Indígena perceberam que somente a publicização e a politização de sua condição e de sua causa a partir da dinamização de uma voz-práxis direta, dos próprios indígenas por si mesmos e desde si mesmos, sem mediações institucionalistas, poderiam desvelar e problematizar a situação indígena no país, os escritores indígenas perceberam que somente produzindo suas próprias obras poderiam tanto descontruir a imagem caricata, folclórica e negativa feita de modo extemporâneo sobre seus povos, quanto reorientar o olhar, reformular a compreensão e recriar a imagem desses mesmos indígenas. Nesse sentido, a literatura indígena brasileira vincula-se diretamente ao Movimento Indígena e objetiva a publicização e a politização dos povos indígenas, constituindo-se em uma voz-práxis ativista, militante e engajada, em que o eu-nós lírico-político assume a promoção da singularidade antropológica e da diversidade cultural, e a denúncia da exclusão, da marginalização e da violência como seu objetivo e seu direcionamento mais básicos, buscando superar a invisibilização, o silenciamento e o privatismo a que os povos indígenas foram submetidos em nossa sociedade.

Palavras-chave: Movimento Indígena; Literatura Indígena; ativismo.

1 Doutor em Letras pela Pontifícia Universidade Católica do Rio Grande do Sul (PUCRS), professor do Departamento de Filosofia da Universidade Federal de Rondônia (UNIR): $<$ lenofranciscodanner@gmail.com>.

2 Doutoranda em Teoria da Literatura pelo Programa de Pós-Graduação em Filosofia da (PUCRS): <juliedorrico@gmail.com>.

3 Doutor em Filosofia (PUCRS), professor do Departamento de Filosofia da Universidade Federal de Rondônia (UNIR): <fernando.danner@gmail.com>. 


\section{CONSIDERAÇÕES INICIAIS}

Neste artigo, nós correlacionamos o surgimento do Movimento Indígena brasileiro, a partir de meados da década de 1970, com a emergência e a constituição da literatura indígena brasileira, a partir da década de 1990. No primeiro caso, as lideranças, os intelectuais e as comunidades indígenas perceberam que somente sua organização e associação como grupo coeso, somadas a sua consolidação e ao seu ativismo na esfera público-política e como sujeito público-político possibilitariam o enfrentamento das situações de exclusão, de marginalização e de violência vividas e sofridas, ainda hoje, no contexto do Brasil contemporâneo. Nesse caso, o objetivo foi o de consolidar uma perspectiva político-cultural em que os próprios indígenas assumiam-se como protagonistas, como sujeitos políticos atuantes na esfera pública, superando a mediação institucionalista e tecnicista à qual até então estavam submetidos pelo Estado e pelas Igrejas Católica e Evangélica. Falar por si mesmos e desde si mesmos, diretamente e sem mediações, na esfera pública e como sujeitos público-políticos, foi, para os indígenas, o caminho para o enfrentamento do etnocídio em curso no Brasil contemporâneo, e aqui está o fundamento do Movimento Indígena brasileiro.

No mesmo diapasão, a literatura indígena brasileira emerge e se constitui a partir da percepção, por parte de intelectuais e escritores indígenas, dequea imagem, a compreensão, oolharea história dose sobreos povos indígenas não apenas eram produzidas por sujeitos extemporâneos e a partir de olhares-visões extemporâneos (e etnocêntricos), mas, no mais das vezes, assumiam um sentido caricato e folclórico, em que esses mesmos povos indígenas apareciam como seres do passado, confinados ao âmbito do mato pura e simplesmente, sem voz, sem vez e sem protagonismo no presente. A literatura indígena, assim, tem sua razão de ser exatamente no fato de que, inserindo-se no Movimento Indígena e buscando sua promoção normativo-cultural, os escritores e os intelectuais indígenas passaram a produzir e a publicizar sua própria criação estético-literária-cultural, a partir de um relato autobiográfico, testemunhal e mnemônico de sua singularidade antropológica e de sua condição de marginalização, de exclusão e de violência como minorias político-culturais.

Nesse sentido, a voz-práxis estético-literária indígena é, em primeira mão, de modo direto, pungente, carnal e vinculado, relato autobiográfico, testemunhal e mnemônico tanto da condição étnico-antropológica como diferença-alteridade quanto da situação de exclusão, de marginalização e de violência como minoria político-cultural. Ou seja, a literatura indígena 
constitui-se como voz-práxis ativista, militante e engajada na esfera pública, como sujeito público-político, aliando-se ao Movimento Indígena em termos de publicização e de politização da condição e da causa indígenas.

No presente artigo, perceberemos que essa necessidade de expressão e de afirmação da própria voz em termos públicos, políticos, culturais e epistêmicos demarcou e dinamizou tanto a constituição do Movimento Indígena quanto, para nosso caso aqui, o desenvolvimento da literatura indígena, em escritores como Kaká Werá, Daniel Munduruku, Ailton Krenak, Álvaro Tukano, Eliane Potiguara, Davi Kopenawa, bem como de muitos outros, que não citamos por esse momento. Nosso argumento central, concernente à imbricação e à mútua dependência de Movimento Indígena e literatura, concernente ao próprio desenvolvimento da literatura indígena brasileira hodierna, está em que, para os intelectuais e para as lideranças indígenas, somente a publicização da própria voz, somente o ativismo, a militância e o engajamento do sujeito lírico-político indígena em termos culturais poderia viabilizar uma perspectiva crítico-criativa dos indígenas por si mesmos e seu reconhecimento sociocultural e político-institucional, o que significa que o ativismo estético-literáriopolítico, ele e somente ele, é quem fundaria a cidadania indígena.

\section{INDÍGENAS EM MOVIMENTO, LITERATURA INDÍGENA: O INDÍGENA NA ESFERA PÚBLICO-POLÍTICA E COMO VOZ- -PRÁXIS ESTÉTICO-LITERÁRIA}

O Movimento Indígena brasileiro surge a partir de fins da década de 1970 como uma estratégia de autoafirmação, resistência e politização da condição, da questão e da causa indígenas, buscando consolidar o protagonismo político-cultural dos povos, das lideranças e dos intelectuais indígenas no cenário nacional e internacional (cf. KRENAK, 2015, p. 25). Conforme dito acima, tratou-se de uma estratégia desesperada de sobrevivência contra a colonização institucional por parte de órgãos políticos (SPI e Funai) ${ }^{4}$ e de Igrejas católicas e evangélicas, e contra a

\footnotetext{
4 Segundo Rubens Valente (2017, pp. 24-45), a extinção do SPI, Serviço de Proteção ao Índio, deu-se em razão de generalizada corrupção, sendo que a consequente criação da Funai, Fundação Nacional do Índio, em 1967, seguiu as contradições do antigo órgão, posto que estava sob responsabilidade do Ministério do Interior. Ou seja, nas palavras de Valente, "o ministro que pregava o desenvolvimento e a ocupação da Amazônia era o mesmo que deveria zelar pelos direitos dos índios que lá viviam, acossados pelos projetos agropastoris que começavam a sair do papel” (p. 45).
} 
destruição material levada a efeito pelas sucessivas ondas de ocupação das regiões Norte e Centro-Oeste (promovidas na época do Regime Militar). O Movimento começou com povos, lideranças e intelectuais indígenas do Alto Rio Negro, no Amazonas, e ramificou-se gradualmente por todo o Brasil, a partir da percepção de que a situação dos povos indígenas brasileiros era absolutamente a mesma: negação e destruição intensificadas (cf.: TUKANO, 2017, pp. 13-26).

Diante desse quadro de ameaça real à própria existência dos povos indígenas, o Movimento Indígena brasileiro assume um papel de protagonismo público, político e cultural, expressando diretamente a voz e as necessidades dos povos indígenas ao longo do Brasil, buscando, além disso, consolidar esses mesmos povos como sujeitos e condição públicos, políticos e culturais. ${ }^{5}$ Em tudo isso, a percepção de que somente a própria voz-práxis direta, carnal e pungente, dos indígenas por si mesmos e desde si mesmos, poderia se constituir em alternativa teórico-política para o enfrentamento da condição de exclusão, de marginalização e de violência demarcou a organização dos povos, das lideranças e dos intelectuais indígenas em torno do Movimento Indígena, o que também implicou a busca pela superação da colonização institucional, enquanto chave e estratégia para vinculação e inserção público-políticas dos povos indígenas, algo muito comum no trabalho de assimilação e de orientação desses povos pelo governo federal e pelas missões religiosas (e, em verdade, em comum acordo entre essas instituições) à época. Sobre a emergência do Movimento Indígena brasileiro e seu mote central, diz Ailton Krenak (2015, p. 220):

As pessoas se perguntam o que tanta gente diferente que se encontrou naquele momento, índios de diversas etnias, ribeirinhos, seringueiros, podiam ter em comum. O que tinham em comum era o medo do progresso! No nosso caso, muito mais do que isso, era o medo do branco. Mas não de um branco qualquer. Existe todo um esquema, um acúmulo de capital... $\mathrm{O}$ índio achou que não sobreviveria a isso.

Por outras palavras, foram a resistência e o enfrentamento a um modelo de desenvolvimento socioeconômico imposto tecnocraticamente e realizado por meio da usurpação das terras indígenas e de destruição dos próprios povos indígenas, que pressupunha, como condição de tudo

5 Cf.: Tukano (2017), Werá (2017 e 2016), Krenak (2015 e 2017), Munduruku (2012), Kopenawa; Albert (2015), Baniwa (2006) e Valente (2017). 
isso, a deslegitimação e a invisibilização do indígena, que impulsionaram a organização do Movimento Indígena brasileiro, enquanto sujeito, causa e condição público-políticos. Movimento Indígena que também buscou, em consequência, a superação do paternalismo institucional a que os indígenas estavam submetidos. Falar e agir em primeira pessoa, direta, carnal e pungentemente, nesse caso, era uma imperiosidade aos povos indígenas, às suas lideranças e aos seus intelectuais; aparecer e consolidar-se na esfera pública e como sujeitos público-políticos foi a alternativa encontrada para enfrentar essa situação de marginalização e destruição em crescimento ao longo desse período. Esse foi o grande mote que demarcou e dinamizou a politização dos indígenas, politização no sentido de que tornariam a floresta em esfera público-política, como causa-condição-questão público-política, e os povos da floresta, como sujeitos público-políticos. Novamente é Ailton Krenak (2015, p. 248) quem nos fala, acerca da emergência e da constituição do Movimento Indígena:

\footnotetext{
Eu acho que teve uma descoberta do Brasil pelos brancos em 1500, e depois uma descoberta do Brasil pelos índios nas décadas de 1970 e 1980. A que está valendo é a última. Os índios descobriram que, apesar de eles serem simbolicamente os donos do Brasil, eles não têm lugar nenhum para viver nesse país. Terão de fazer esse lugar existir dia a dia. Não é uma conquista pronta e feita. Vão ter de fazer isso dia a dia, e fazer isso expressando sua visão de mundo, sua potência como seres humanos, sua pluralidade, sua vontade de ser e de viver.
}

A organização da União das Nações Indígenas (UNI) e da Aliança dos Povos da Floresta, bases do Movimento Indígena brasileiro, foi a consequência dessa politização e publicização dos povos indígenas, de suas lideranças e de seus intelectuais, consequência das discussões coletivas e institucionais. Ora, como a consciência da necessidade desse ativismo específico era praticamente um consenso entre todas as lideranças e todos os intelectuais indígenas fundadores e continuadores do Movimento Indígena (Álvaro Tukano, Raoni Metuktire, Mário Juruna, Marcos Terena, Angelo Kretã, Davi Kopenawa, Ailton Krenak, Kaká Werá, Daniel Munduruku, Gersem Baniwa etc.), a politização e a publicização da causa-questão indígena passaram a ser uma prioridade para esses povos e o pilar básico para a fundação do Movimento Indígena como organização político-cultural direcionada ao diálogo direto com a sociedade civil e com as instituições jurídico-políticas, um diálogo politizado em que os povos indígenas assumiam o protagonismo da causa-condição indígena. 
Como resultado dessa articulação política dos povos indígenas do Movimento Indígena, e como Movimento Indígena, desde então se tem uma forte vinculação pública e um intenso ativismo cultural de organizações correlatas, como é o caso da Articulação dos Povos Indígenas do Brasil (APIB), um desdobramento contemporâneo do Movimento, conforme se pode perceber em sua página na internet. ${ }^{6} \mathrm{O}$ objetivo da APIB, que foi criada em 2005 pelo Acampamento Terra Livre (este vigente desde 2004 até hoje), é o enquadramento de nossas instituições relativamente às condições, às demandas e aos direitos dos povos indígenas brasileiros - o que significa exatamente essa postura permanente e pungente de participação, de crítica, de diálogo com a sociedade civil, com nossas instituições e com nossos sujeitos público-políticos hegemônicos (como, por exemplo, os partidos políticos tradicionais à nossa esfera pública e às nossas instituições). ${ }^{7}$ Sem ignorar todo o papel sociocultural assumido pelos indígenas ao longo do desenvolvimento do Brasil, podemos dizer, conforme vimos pela fala-práxis de Ailton Krenak citada acima, que a politização e a publicização dos povos indígenas, como sujeito, condição e questão coletivos, nacionais, deram-se nesse contexto da década de 1970 em diante, via ativismo, militância e engajamento no e do Movimento Indígena (KRENAK, 2017, p. 25). Ainda segundo o autor:

A UNI iniciou a sua articulação mais permanente em 1979. Hoje, o Brasil sabe
que existe o povo indígena. Acho que vocês sabem que, na década de 1960 e até
o começo da década de 1970, mesmo as pessoas mais bem-informadas do Brasil,
se perguntassem a elas sobre os índios, iam dizer: "não, índio não. Não tem.
Bem, talvez tenha um ou outro aí guardado em alguma reserva pelos irmãos
Villas Bôas". "Quem são os irmãos Villas Bôas?", outro diria. "São heróis que
têm lutado para guardar como relíquia alguns índios sobreviventes de 150o".
Raoni Metuktire trouxe para o povo brasileiro e para o mundo cheiro de índio,

6 Disponível em: <www.apib.info >. Acesso em: 10 out. 2018.

7 A APIB possui três propósitos fundamentais, a saber: "fortalecer a união dos povos indígenas, a articulação entre as diferentes organizações indígenas do país; unificar as lutas dos povos indígenas, a pauta de reivindicações e demandas e a política do movimento indígena; mobilizar os povos e as organizações indígenas do país contra as ameaças e as agressões aos direitos indígenas". A APIB encampa e promove discussões em torno de pontos como legislação indigenista, saúde e educação escolar indígenas, gestão territorial e territorialidade, participação e controle social. Ela reúne as seguintes organizações indígenas regionais: Articulação dos povos indígenas do Nordeste, Minas Gerais e Espírito Santo (APOINME), Conselho do Povo Terena, Articulação dos Povos Indígenas do Sudeste (ARPINSUDESTE), Articulação dos Povos Indígenas do Sul (ARPINSUL), Grande Assembleia do Povo Guarani (ATY GUASU), Coordenação das Organizações Indígenas da Amazônia Brasileira (COIAB) e Comissão Guarani Yvyrupa. 
cara de índio, impressão sobre o índio, expectativa. Em alguns casos, irritação, ódio, carinho, solidariedade. Nós provocamos sentimentos nas pessoas quando mostramos que éramos gente de verdade. Nós provocamos os fazendeiros. Nós provocamos o Conselho de Segurança Nacional, que botou os militares para nos vigiar mais de perto. Mas, em compensação, nós lembramos a milhares de pessoas que ainda estamos vivos e que queremos ser amigos dessas pessoas. $\mathrm{E}$ isso é solidariedade. É uma palavra que não conhecíamos, mas uma ideia que praticamos há milhares de anos. (2015, p. 88)

Portanto, no núcleo da emergência, da constituição e da vinculação público-política do Movimento Indígena brasileiro estava a intenção correlata de fundar, de dinamizar e de consolidar essa voz-práxis público-política; e a consequência consentânea de visibilizar a singularidade antropológica do indígena e sua condição de vítima de nossa modernização conservadora, de modo a conscientizar e educar a sociedade brasileira quanto à situação indígena no país. É muito importante prestarmos atenção a este último ponto: os intelectuais e as lideranças indígenas desde cedo perceberam que essa publicização, que essa visibilização dos povos indígenas em termos públicos, políticos, culturais e institucionais poderia conceder hegemonia à condição e à causa indígenas e, por isso mesmo, todas as lideranças e todos os intelectuais indígenas acima citados colocam esse contato - seja por meio de eventos culturais e do ativismo dessas lideranças e desses intelectuais, seja por meio de publicações e da interação com escolas e universidades - como base e instrumento fundamentais para visibilizar a causa e a condição indígenas, para politizá-las, para ganhar adeptos na sociedade civil de um modo mais geral.

Como pudemos perceber nas palavras de Ailton Krenak, acima, as pessoas ficaram sabendo que os povos indígenas existem, que eles têm um presente, que eles não são apenas figuras mitológicas nem sujeitos do passado, mas que são exatamente contemporâneos de todos nós. Que eles existem como povos, possuem intelectuais e lideranças politizados, e isso porque se organizaram, apareceram e se consolidaram em termos público-políticos, assumindo protagonismo político-cultural, dando-se a conhecer e propondo-se a dialogar com a sociedade civil de um modo geral e com as instituições políticas em particular. Aqui, o falar por si mesmo e desde si mesmo, diretamente e sem mediações, e o dar-se a conhecer em termos públicos, políticos e culturais andam de mãos dadas, apoiam-se mutuamente, permitindo que os povos indígenas possam de

8 Cf., ainda: Jecupé (2002, p. 52). 
modo correlato e imbricado problematizar politicamente sua situação e buscar hegemonia cultural junto à sociedade civil. Não por acaso, esses povos veem na educação das crianças e dos jovens, nas escolas e nas universidades, alguns dos momentos mais fundamentais de sua atuação em termos públicos, políticos e culturais, sendo uma das arenas e estratégias mais básicas da atuação do Movimento Indígena e de sua produção estético-cultural. Sobre isso, Álvaro Tukano (2017, p. 26) afirma:

Para mim, é muito bonito falar para os jovens que dependemos dessa terra, dependemos dos frutos da terra, das águas. Então é por isso que a gente quer a nossa comunicação com os estudantes e universitários. Seja índio ou branco, a gente tem de fazer uma nova sociedade. O Brasil precisa ser dirigido pelos novos, menos contaminados por essa prática de evangelizar e tutelar o índio. Se a tutela fosse uma salvação de fato, eu bateria palmas. Mas tem limitado a minha voz, tem atado as minhas mãos e de outros líderes também. Então, o que estou falando é para desatar esse pano que tem vendado as vozes das lideranças, as mãos das lideranças. Acho que o público tem de ouvir diretamente o que os verdadeiros líderes pensam, falam e defendem sobre a questão indígena. ${ }^{9}$

A sociedade necessita ouvir diretamente a voz dos intelectuais e das lideranças indígenas, ela precisa perceber o protagonismo político, cultural e normativo desses povos, situação que é viabilizada seja pelo ativismo na esfera público-política e como sujeitos público políticos, seja pela produção e pela divulgação estético-cultural dinamizada gradativamente pelos intelectuais e pelos escritores indígenas, em particular pela literatura indígena que passa a se desenvolver, a partir dos anos 1990, em profunda consonância com o Movimento Indígena e com esse seu mote de politização, de publicização e de busca por hegemonia cultural (cf.: GRAÚNA, 2013, pp. 15-45; SÁ, 2012, pp. 19-37; THIÉL, 2012, p. 44). Ora, há uma correlação entre a emergência e o protagonismo do Movimento Indígena e a conquista de visibilidade, a constituição e a vinculação público-política da literatura indígena brasileira que se desenvolve no Brasil a partir dos anos 1990. Daniel Munduruku (2018) corrobora esse argumento, ao contar que os direitos conquistados e assegurados pela militância articulada no e pelo Movimento Indígena na década de 1970 viabilizaram a atuação dos povos indígenas em relação aos interesses dos seus grupos, mas também possibilitaram que vários grupos indígenas

9 Cf., ainda: Werá (2017, pp. 29-30), Munduruku (2016b, pp. 187-192), Krenak (2017, pp. 59-64), Jekupé (2009, pp. 7-21) e Baniwa (2006, pp. 216-225). 
passassem a reivindicar demandas ligadas "à saúde, à educação, à arte. E, inclusive, à literatura” (MUNDURUKU, 2018, p. 33).

Se o Movimento Indígena surge, se desenvolve e se vincula público-politicamente, e o faz com o objetivo de resistir a um processo de destruição massivo contra os povos indígenas, com o objetivo de falar diretamente à sociedade, com o objetivo de superar sua invisibilização e seu silenciamento; no mesmo diapasão, a literatura indígena passa a ser desenvolvida por escritores indígenas exatamente a partir da percepção de que a imagem pública, cultural e normativa acerca do indígena era uma imagem caricata e folclórica, basicamente representada, construída e legitimada por escritores não indígenas, uma imagem, uma representação que os colocava como seres do passado, não do presente, como seres menores, pré-modernos, cujo lugar no mundo contemporâneo seria, no máximo, as reservas federais, como animais, junto com os animais, no mais recôndito da floresta. Esse incômodo com tal situação, conforme relata Daniel Munduruku (2016b, pp. 172-173), foi que o levou a tornar-se escritor indígena, de forma a construir e a publicizar uma imagem dos povos indígenas que fosse formulada, narrada e explicitada por eles próprios:

Num dia qualquer, uma menininha quis saber onde ela poderia encontrar as histórias que eu contava para que pudesse ler. Aquela pergunta me pegou de "calças curtas", como se diz. Eu não poderia dizer a ela a bibliografia da USP e nem soube indicar livros que continham as histórias. Na verdade, fiquei sem resposta. Dias depois, fui a uma grande livraria da cidade e pedi para o vendedor me mostrar onde estavam os livros para crianças que tratavam da temática indígena. Ele me apresentou uma prateleira que trazia uma plaquinha escrita: folclore. Mesmo achando estranha a descrição, fui olhando título a título. Encontrei vários livros abordando o tema, mas nenhum deles escrito por indígenas. Boa parte era mesmo narrativa folclórica dos personagens já conhecidos. Vez ou outra, encontrei alguns títulos que narravam histórias e traziam informações sobre os povos de onde tinham sido extraídas. A maioria, no entanto, repetia a visão estereotipada e excludente, fazendo os leitores acreditar que os povos indígenas eram coisa do passado. Eu tinha que procurar reverter esse quadro. Não era justo que nossos povos figurassem como folclore nas prateleiras, como se fossem personagens de um passado que não existia mais.

Note-se a correlação entre a emergência do Movimento Indígena e a emergência da literatura indígena: tratava-se de mostrar que os indígenas não eram nem figuras folclóricas e sujeitos do passado, e nem subcidadãos ou menos que isso. Para eles, tratava-se de publicizar-se para politizar-se, de romper com o silenciamento e com a invisibilização como condição da 
cidadania política e do protagonismo cultural, como condição, inclusive, da crítica social e da resistência político-cultural contra a destruição em curso. Desse modo, essa tomada de consciência em relação à centralidade da esfera pública, política e cultural, em relação à necessidade de protagonismo público, político e cultural por si mesmos e desde si mesmos é o que caracteriza o surgimento do Movimento Indígena e, nele, da literatura indígena brasileira hodierna; é o que demarca a mútua projeção, a ligação umbilical e a reciprocidade entre um e outra.

Aqui, a utilização das ferramentas formais (escrita, editoração, mídias digitais etc.), a ocupação da esfera pública e dos espaços culturais e o ativismo, a militância e o engajamento políticos direcionam-se à visibilização dos povos indígenas, ao fomento de sua singularidade antropológica como alteridade-diferença, à denúncia de sua condição de marginalização, de exclusão e de violência, e, finalmente, à busca por hegemonia cultural e política, que, como dissemos, somente foram e são possíveis por meio da publicização e da politização. Assim, as armas ideológicas dos brancos, da civilização passam a ser apropriadas pelos povos indígenas com um objetivo bem claro, a saber, autoafirmação, resistência e luta, publicização e politização do sujeito indígena, de sua condição e de sua causa. Conforme Kaká Werá (2017, pp. 119-120) diz:

\begin{abstract}
Os povos indígenas, num determinado momento, principalmente da década de 1960, desenvolveram certo pensamento: "Agora não devemos lutar para resgatar aquilo que nós éramos antes, agora é hora de analisar o que fizeram conosco e pensar no que vamos fazer daquilo que fizeram de nós". E, quando começamos a pensar o que podemos fazer daquilo que fizeram de nós, veio a estratégia, surgida a princípio entre os Xavantes e entre os Guaranis, de aos poucos tomar as ferramentas da sociedade chamada civilizada, seus códigos, tecnologias, pedagogias, e utilizá-las de modo a veicular os valores e a visão do mundo das matrizes ancestrais do Brasil. Afinal, embora sufocada, a essência e o espírito de cada cultura nativa continuam presentes sob o disfarce da colonização. ${ }^{10}$
\end{abstract}

Os indígenas não são figuras do passado, mas do presente - eis a grande invectiva do Movimento Indígena de um modo geral e da literatura indígena brasileira em particular. Como seres do presente, possuem sua singularidade e a afirmam; como seres do presente, assumem protagonismo político-cultural e, uma vez consolidando-se na e como esfera pública, fundam a cidadania indígena desde uma perspectiva ativista, militante e engajada, denunciam a condição de

10 Cf., ainda: Tukano (2017, p. 27) e Munduruku (2017, pp. 122-123). 
vítimas da modernização conservadora brasileira, acreditam-se com capacidade de ensinar e de dialogar com a sociedade brasileira. Conforme Ailton Krenak, instituições políticas e culturais, mormente ao Estado em seu tratamento para com eles, instituições essas que agiam como se os indígenas não existissem ou como se fossem menores, incapazes de reflexividade e de atuação cidadã, como se devessem ser confinados às matas, como sub-humanos, portanto. É justamente contra essa situação de negação da cidadania e de deslegitimação antropológica, cultural e política que a atuação público-política dos povos indígenas reage, é ela que o protagonismo indígena almeja superar. Nesse sentido, de seres do passado, concebidos de modo caricato e tematizados desde uma perspectiva folclórica, eles passam a assumir-se e a portar-se como seres do presente, o que significa consolidar-se como condição e como questão público-política, como sujeitos público-políticos, atuantes, militantes e engajados, colocando-se como parte fundamental do Brasil, mas não o Brasil do passado, e sim o do presente juntamente com sua projeção futura; os indígenas como protagonistas do Brasil do futuro, a partir de seu ativismo no presente.

\footnotetext{
Essa relação (entre instituições e povos indígenas, no Brasil) sempre se baseou em um ponto de vista hipócrita. E, por isso, nunca houve o menor esforço para defini-la melhor. Para o governo, para todos os governos que se sucederam na história deste país, o problema está resolvido: ignora-se o direito à existência dos índios. A própria imagem que nos é passada na escola conta-nos a seguinte história: "quando Cabral chegou, o Brasil era habitado por índios". Aí fecha rápido a cortina e pronto: “não há mais índios!”. Acontece que há. O Estado prefere continuar ignorando o direito à existência de índios no Brasil, mas eles começam a se fazer representar junto às instituições. (KRENAK, 2015, p. 23)
}

Ora, uma das formas mais interessantes dessa representação institucional e desse protagonismo é a já apresentada inserção desses povos na literatura, que vai da tradição ancestral à crítica do presente, imbricandoautoafirmação e autoexpressão étnico-identitárias com e como crítica do presente, resistência cultural, luta política e práxis pedagógica. Graúna (2013, p. 170) argumenta que as vozes ancestrais sugerem mais e mais desafios que emanam da literatura indígena contemporânea, que são viabilizados por esta: "um mundo espelhado de mundos, de sonhos e realidades distintas; um mundo de pessoas que foram impedidas de expressar o seu pensamento ao longo dos mais de 500 anos de colonização". A literatura indígena - como de resto a literatura de minorias de um modo geral - explicita as vozes de grupos marginalizados que se politizam e se 
vinculam na esfera pública em torno da causa e da condição indígenas. É o que veremos a partir de agora.

\section{DA CARICATURA E DO FOLCLORE AO ATIVISMO E À MILITÂNCIA: A DINÂMICA DA LITERATURA INDÍGENA BRASILEIRA}

A literatura indígena, conforme expusemos, é um instrumento político, uma plataforma político-cultural que tem como escopo a autoafirmação, a autoexpressão e a vinculação pública, política, cultural, institucional e normativa dos sujeitos indígenas, o que a leva a aliar-se profundamente ao Movimento Indígena. Em primeiro lugar, diferentemente de posições altamente institucionalistas, cientificistas e tecnicistas, próprias à filosofia, à teologia e à ciência, a literatura permite a abertura paradigmática e uma perspectiva antissistêmica, anticientificista e antitecnicista marcadas pela inclusão, pela participação e pelo envolvimento entre diferentes sujeitos epistemológicos-políticosestéticos, que não o cientista racional, o profissional lógico-técnico e o político partidário-institucional estratégico. Na literatura, diferentemente da ciência, da filosofia e da teologia (assim como da própria política institucional e partidária, que trabalha e se dinamiza por representação e por delegação dos poderes de fala, de decisão, de ação), a fala-práxis não tem necessidade de assumir uma perspectiva técnica, formalista e institucionalizada, metodologicamente guiada e definida a partir de uma comunidade de pesquisa especializada autorreferencial, autossubsistente e autossuficiente, endógena e autônoma, que exclui o senso comum e as pessoas comuns - entenda-se o contexto e os sujeitos não científicos, isto é, não objetivos - da possibilidade de dizerem e agirem objetivamente (objetividadeque somenteé possível por meio da ciência institucionalizada e dinamizada desde uma perspectiva técnica, endógena, autorreferencial e autossubsistente).

Na ciência institucionalizada e tecnicista, portanto, o senso comum e as pessoas comuns aparecem não apenas como diminuídos, não objetivos, mas também como mediados pela fala e pela ação técnicas do especialista institucionalizado (e como necessitando dessa mediação especializada, institucionalizada e tecnicista, enquanto condição da justificação, da validade e da objetividade), calcado em uma ciência objetiva, neutra, imparcial, impessoal e formalista. A literatura de minorias, em contrapartida, possibilita, como dizíamos, uma abertura paradigmática 
a diferentes estilos de fundamentação, que são caudatários de múltiplas formas de expressão; fomenta a participação e a publicização de diferentes sujeitos epistemológico-políticos, a partir de sua singularidade antropológica; e permite-viabiliza o relato autobiográfico, testemunhal e mnemônico da própria condição de marginalização, de exclusão e de violência. De todo modo, o que queremos significar com isso é que a literatura permite a expressão direta do próprio sujeito lírico, sem mediações institucionalistas, cientificistas e tecnicistas, mediações essas queo despolitizam, retirando-lhea carnalidadeeavinculaçãoa partirdesse ideal de objetividade como institucionalização e produção tecnicistas do conhecimento e da ação por meio de um especialista imparcial, impessoal, neutro e formalista basicamente apolítico-despolitizado, descontextualizado, desvinculado do horizonte de pertença e de atuação dos sujeitos cotidianos - mediação que substitui as vítimas, os sujeitos cotidianos pelo especialista, pelo técnico institucionalizado, objetivo, porque imparcial, neutro, formal e impessoal. Na literatura de minorias, na literatura indígena, é o próprio sujeito que fala diretamente, desde sua singularidade, desde sua vinculação e sua ligação cotidianas, desde sua carnalidade e politicidade. Nesse sentido, a literatura indígena é instrumento político porque busca conceder ao indígena uma voz-práxis direta, um protagonismo público-político, sociocultural, epistemológico-normativo; ela lhe possibilita ser o artífice da próprio condição e causa indígenas, sem mediações, de modo a superar sua invisibilização, seu silenciamento e seu privatismo, e a consolidar, em consequência, a cidadania indígena que, como dissemos na primeira parte deste texto, foi o grande mote e a grande estratégia do Movimento Indígena em termos de reafirmação, resistência e luta contra a marginalização, exclusão e destruição feitas em termos de modernização periférica e conservadora. Sobre isso, Kaká Werá (2017, p. 29, grifo nosso) salienta:

Para nós, a literatura indígena é uma maneira de usar a arte, a caneta, como uma estratégia de luta política. É uma ferramenta de luta. E por que uma luta política? Porque, à medida que a gente chega na sociedade e a sociedade nos reconhece como fazedores de cultura, como portadores de saberes ancestrais e intelectuais, ela vai reconhecendo também que existe uma cidadania indígena. E que dentro da cidadania existem determinados direitos constitucionais que não ferem, que não desagregam a sociedade, seja indígena ou não-indígena. Ao contrário, que dão legitimidade, suporte e fortalecem em questões que hoje são cruciais para a sociedade humana como um todo. ${ }^{11}$

11 Cf., ainda: Almeida e Queiroz (2004, p. 199). 
Cidadania política é uma questão de visibilidade, de publicização, de politização, de participação na esfera público-política e como sujeito público-político, em busca de hegemonia cultural e institucional - a cidadania política, aliás, para as minorias político-culturais, é questão de vida e de morte, como podemos perceber em nossa sociedade brasileira atual, na qual, sem a participação e a vinculação permanentes e pungentes dessas mesmas minorias na esfera pública ecomo sujeitos público-políticos, as posições conservadoras, hegemônicas partidária e institucionalmente, centralizam e monopolizam o grosso da evolução social, da construção de políticas públicas, da atuação cotidiana das instituições (cf.: DANNER; DORRICO, 2018, pp. 197-233; DALCASTAGNÈ, 2012, pp. 7-33). Cidadania política é uma questão de ativismo, militância e engajamento permanentes e pungentes, que superam a invisibilização, o silenciamento e o privatismo impostos a essas minorias, que levam ao enfrentamento direto dos sujeitos, das instituições, das práticas e dos valores essencialistas e naturalizados, a-históricos e apolíticos-despolitizados que sustentam a marginalização, a exclusão e a violência contra as minorias, que sustentam a produção e a manutenção das minorias.

De fato, como vimos na primeira parte deste texto, as lideranças e os intelectuais indígenas brasileiros, fundadores de nosso Movimento Indígena, perceberam que essa condição de vinculação e de ativismo público-políticos, de crítica social e de resistência cultural se colocariam como bases tanto para a reafirmação dos povos indígenas quanto para o enfrentamento por eles do etnocídio em curso. É nesse sentido que a literatura indígena emerge como instrumento político, como voz-práxis política diretamente engajada ao Movimento, em termos de ativismo e militância na esfera público-política. Pela própria natureza dos povos indígenas - profunda dependência entre comunidade-grupo e indivíduo, que, conformepensamos, gera umeu-nós lírico-político emqueointelectual ou escritor parte de sua singularidade enquanto grupo e estabelece uma postura de crítica do presente, relativamente à condição de vítima desse mesmo grupo -, essa literatura visa à publicização da diversidade cultural dos povos indígenas, seja na fundação de uma perspectiva de crítica social e de resistência cultural, seja na de luta política em torno d condição e da causa indígenas. Como exemplo desse nosso argumento, podemos citar o poema do escritor indígena Tiago Hakiy (2011, p. x) que, em seus versos, denota uma voz-práxis lírico-política consciente do papel de resistência pela palavra, constituída em termos literários, seja em poesia ou prosa: 


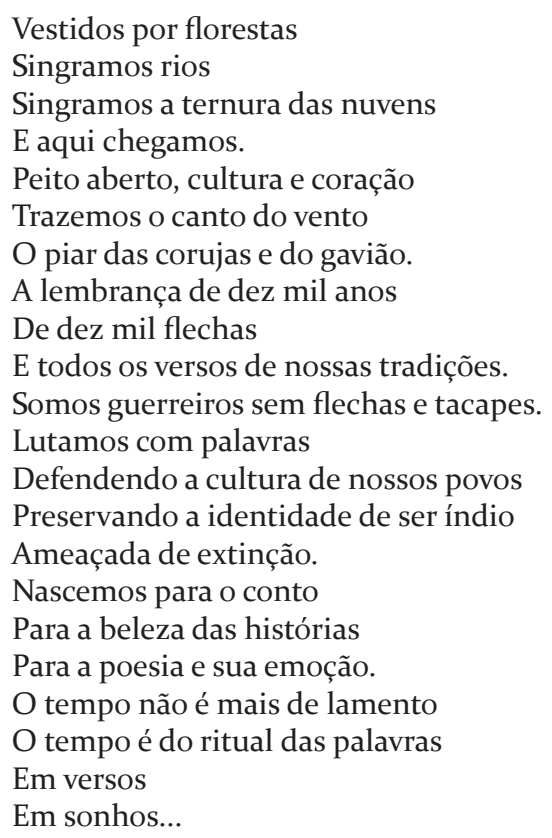

Esses versos evocam a e se utilizam da memória ancestral, enfatizando lexicalmente a pertença do sujeito indígena por meio dos termos flechas, tacapes, povo, conto, corujas, gavião, guerreiros. Contudo, tais evocações não se encerram no louvor a um tempo passado, senão que o tomam como mote central para arguir sobre a importância da reafirmação da alteridade, o que aponta para uma postura consciente acerca da necessidade de resistência política como condição para a reafirmação e para a sobrevivência dos povos indígenas diante de nosso processo de modernização conservadora. Por isso, quando o eu lírico enuncia que o tempo é do ritual das palavras, ele, a partir de sua experiência de violência histórica, física e simbólica, reitera sua autoconsciência, autoafirmação da identidade, autovalorização de seus saberes tradicionais. Esse movimento de afirmação e pertença étnica, do sujeito individual que tem como condição fundamental a sua coletividade, revela que o eu-nós lírico-político, nos versos de Hakiy, correlaciona potência estética e ativismo político, por meio da retomada e da reatualização de sua ancestralidade, agora eivada da palavra escrita, orgulho e consciência da luta política que tem de enfrentar. Gostaríamos de enfatizar essa ideia de que agora, hoje, neste exato momento, "o tempo é das palavras", o que significa que a luta 
é pelas palavras, com as palavras - palavras que são públicas, políticas em primeira mão.

Quanto à emergência da literatura indígena, a partir de 1990, Kaká Werá (2017, pp. 25-26, grifos nossos) afirma que:

\begin{abstract}
Naquela mesma época, em nossos encontros na aldeia Guarani, eu conversava muito com o Daniel Munduruku. Ele já era um educador, formado em filosofia, e dava aula em escola pública. A gente conversava muito sobre como encontrar maneiras de potencializar esse trabalho de difusão. E tanto ele quanto eu gostávamos muito de literatura. Então nós sonhamos, naquela época não era ainda criar um movimento de literatura indígena, mas em usar a escrita para falar das nossas culturas. Para falar diretamente. Para se ter uma ideia, até o início dos anos 1990, o que se tem notícia é de que praticamente tudo o que existe de escrito no Brasil sobre o índio, sobre os povos indígenas, sobre as culturas indígenas, não foi escrito por um índio. Foi sempre por um indigenista, por um antropólogo, por um sociólogo, por um estudioso, por um artista, por um poeta, por um escritor. Não que eu ache que isso seja uma coisa errada. Mas eu achava que, na medida em que nós nos tornássemos protagonistas de nossas próprias vozes, isso poderia gerar uma força muito grande, uma estratégia muito potente para se comunicar diretamente com a sociedade. $E$ também para a sociedade ouvir diretamente a voz de um intelectual, de um cidadão, de um pensador, de um curador, de um contador de histórias vindo de um povo indígena.
\end{abstract}

Por isso mesmo, há uma forte correlação e uma mútua dependência, na literatura indígena, entre voz-práxis estético-literária, política-politização e educação, de modo que, como reconhecem os escritores indígenas, sua literatura é tanto instrumento político quanto práxis pedagógica que busca a crítica social, a resistência cultural e a luta política, assim como busca hegemonia e transformação por meio da educação - a crítica, a resistência e a luta por meio da práxis pedagógica, como práxis pedagógica -. Por isso a literatura indígena é necessariamente uma literatura militante, ativista e engajada em defesa da causa e da condição indígenas, e sua vinculação pública se dá exatamente como politização direta e incisiva, e como práxis pedagógica. Não é uma literatura voyeurista e descomprometida, mas também não é puramente individualista, pois seu núcleo é sempre caracterizado e dinamizado pela imbricação com o Movimento Indígena. Trata-se de uma literatura que conta sem mediações e de modo nu e cru, por meio de relato autobiográfico, testemunhal e mnemônico, sua singularidade antropológica e sua condição de exclusão, de marginalização e de vítima de violência como minoria político-cultural. Dessa forma, essa literatura explicita, desvela e representa a própria comunidade, o próprio grupo de que faz parte. E a literatura de minorias de um modo geral e 
a literatura indígena, em particular, por essa condição de luta política contra as estigmatizações - os índios são ainda hoje tratados como anormais, decaídos e primitivos - não pode se processar de outro modo que não como ativismo, militância e engajamento, como politização profunda e abrangente não apenas da própria minoria, do próprio grupo, mas da sociedade, de suas instituições, sujeitos sociopolíticos, relações, práticas e valores como um todo, pois, como dissemos acima, as minorias são construções políticas produzidas e legitimadas social e institucionalmente que, ao aparecerem na e como esfera pública, como sujeitos público-políticos, como causa e condição público-políticas, explicitam os próprios déficits de integração social e institucional.

Acerca de sua perspectiva como escritor indígena, Daniel Munduruku (2016b, p. 177) revela que:

[...] para mim a escrita era uma espécie de instrumento pedagógico. Sempre tive no horizonte o objetivo de auxiliar a sociedade brasileira a compreender e a aceitar a diversidade indígena. Era uma questão de honra. Não me via como um escritor, mas como um educador cuja principal tarefa era "jogar piolhos" na cabeça da sociedade e deixar ela se inquietar, pensar, se coçar e refletir sobre a própria identidade étnica. Até hoje penso assim, mas agora já sei que sou um escritor que faz uma literatura militante, comprometida com a transformação social. $^{12}$

Essa literatura militante - como de resto o é toda a literatura produzida pelas minorias desde si mesmas, acerca de si mesmas, por si mesmas marcada pelo desvelamento das situações de exclusão, de marginalização e de violência e pela desconstrução desse sentido negativo em termos políticos, normativos e culturais acerca das minorias, essa militância chega à resistência cultural e à luta política frente às instituições, frente aos sujeitos, às relações e aos valores que geram, sustentam, legitimam e reproduzem essas mesmas minorias como chagas, como normativamente decaídas. Aqui, portanto, a função e a intenção da literatura indígena consistem em desconstruir os estereótipos produzidos sobre os indígenas, em educar ou reeducar a compreensão da população sobre eles para, com isso, pleitear um novo lugar, um novo papel e uma nova simbologia em torno desses povos (e da própria ideia do mato como um lugar arcaico). Sobre o trabalho dos escritores indígenas, como escritores indígenas, que apresentam seu povo como diferenças-alteridades com o direito de ser e

12 Cf., ainda: Jecupé (2002, p. 93), Werá (2017, pp. 120-121) e Krenak (2015, p. 166). 
de viver, com contribuições fundamentais a serem dadas à sociedade em geral, Daniel Munduruku (2016b, pp. 191-192) diz:

\begin{abstract}
Nosso trabalho, portanto, não é nada fácil. Exige que a gente compreenda bem a narrativa engendrada pela sociedade. Exige que a gente entenda a sociedade sem se preocupar se a sociedade nos compreende bem. A tarefa que nos propomos consiste em reeducar as novas gerações de brasileiros para que consigam nos olhar com a dignidade que merecemos. Para isso, não podemos fazer um enfrentamento violento, como nos tempos antigos, mas usar das mesmas armas que foram utilizadas para estabelecer seu preconceito: a escrita e a literatura. Por meio delas, inventaram rivalidades, criaram guerras de extermínio, difundiram estereótipos e preconceitos e, principalmente, dividiram-nos para poderem dominar nossos saberes ancestrais.
\end{abstract}

Note-se que essa compreensão, esse olhar e essa imagem que foram construídos sobre os povos indígenas - e contra os quais a literatura indígena luta - possuem um profundo núcleo normativo, cultural e político que, para ser transposto, exige uma contrapartida, a saber, um novo núcleo normativo, cultural e político, dessa vez produzido, dinamizado e explicitado, como vimos dizendo, pelo próprio indígena a partir de sua voz-práxis direta, carnal e vinculada, a partir de sua perspectiva direta e sem mediações, a partir de sua inclusão, de seu reconhecimento e de sua participação na esfera pública, política, cultural e institucional, em termos de cidadania política e de sujeito cultural. É nesse sentido que a correlação entre Movimento Indígena e literatura indígena é importante, pois, para isso, é necessário que o sujeito epistemológico-político indígena consolide-se na esfera pública e assuma uma perspectiva ativista, militante e engajada, como vêm fazendo Kaká Werá, Ailton Krenak e Daniel Munduruku.

A partir da percepção de que a imagem estereotipada do índio, conforme apresentamos, é feita de modo extemporâneo, preconceituoso e autoritário, por meio de uma perspectiva altamente colonialista, profundamente enraizada nessa visão colonialista e eurocêntrica do Brasil (como uma proto-Europa, como uma modernidade ainda por fazer, na qual não cabe lugar ao não moderno, como se existisse essa cisão entre a modernidade europeia e o outro da modernidade, no caso os povos indígenas, e como se o caminho para o Brasil fosse exatamente esse, tornar-se diretamente uma Europa), Kaká Werá afirma que a grande função da arte-literatura em geral e da arte-literatura indígena em particular consiste nisso que ele chama de descatequização da mente, do olhar, do discurso relativamente aos povos indígenas. Como 
ele reconhece, a expressão estético-literária nacional teve um papel fundamental na descaracterização, na catequização e na caricaturização dos povos indígenas, contribuindo para fundar e sedimentar a imagem negativa dos povos indígenas, bem como para aculturá-los, isto é, para com que perdessem suas raízes e assumissem a identidade branca, eurocêntrica e católica, socioculturalmente hegemônica, via imposição autoritária pelas instituições políticas, culturais, educacionais e religiosas (incluindo-se, aí, a legitimação artístico-literária dessa noção negativa dos povos indígenas e a sobrevalorização e estilização acrítica do modelo eurocêntrico de sociedade, de cultura e de homem).

O índio que se conhece até hoje, nestes últimos 500 anos, é o índio teatralizado. Infelizmente, para a maior parte da população brasileira, o índio é um personagem, não existe de fato. $\mathrm{O}$ Brasil tem uma vaga ideia dessa diversidade de povos que até hoje estão espalhados por aí e tem uma ideia fragmentada do que pensam e das suas visões de mundo, das suas verdades mais profundas. Isso se deve ao fato de a sociedade na qual vivemos ser uma sociedade que mede, julga e reconhece as coisas e as culturas pela sua forma e aparência. (WERÁ, 2017, p. 101)

Mais ainda, isso se deve ao fato de que os povos indígenas não apenas foram e são submetidos a um processo de destruição material acentuado, ao longo do desenvolvimento de nossa sociedade, mas também de que foram confinados no mais recôndito das matas, silenciados, invisibilizados e privatizados por parte de nossos sujeitos, instituições, relações, práticas e valores coloniais. Dessa forma, o índio, pelos olhos, pela compreensão e pelos interesses dos próprios colonizadores, foi visto como o antípoda da colonização enquanto consecução e implantação da civilização nestes trópicos (portanto, alguém que poderia ser apagado, erradicado e deslegitimado, pois não teria nada a dizer e a ensinar - alguém sem qualquer protagonismo).

Nesse contexto, a organização e o fortalecimento do Movimento Indígena e da literatura indígena, enquanto reação a esse processo de colonização, busca a vinculação público-política dos povos indígenas, de suas lideranças, de seus intelectuais e de seus escritores como interlocutores privilegiados, tanto da condição e da causa indígenas quanto da construção de modelos políticos, práticas culturais, valores axiológicos e formas de desenvolvimento alternativos ao nosso padrão propriamente moderno (individualismo, tecnicismo, racionalização, exploração material, industrialismo sem limites, dogmatismo religioso-cultural, representação política partidária etc.). Tornados sujeitos 
público-políticos, como Daniel Munduruku, Ailton Krenak, Kaká Werá e Eliane Potiguara, eles assumem a tarefa de um permanente diálogo, de uma profunda interação com a sociedade em geral, como seres do presente, como seres que querem apresentar suas visões de mundo, suas dores e seus sofrimentos como minorias, como vítimas da modernização conservadora, como povos-culturas que têm muito a ensinar a partir de suas experiências vitais (cf.: MUNDURUKU, 2016a e 2016b, pp. 20-52; KRENAK, 2015, pp. 84-86; POTIGUARA, 2004, pp. 102-104).

Diz-nos Ailton Krenak (2015, p. 239), acerca de seu ativismo em termos de Movimento Indígena e sobre sua produção estético-cultural-literária dele decorrente:

E o outro desconforto era me identificar como índio, porque índio é um erro de português, parafraseando o Oswald, que disse que, quando o português chegou no Brasil, estava uma baita chuva, aí ele vestiu o índio, mas se estivesse num dia de sol o índio teria vestido o português, e estaria todo mundo andando pelado por aí. Isso continua valendo até hoje, e eu atualizei dizendo que o índio é um equívoco do português, não um erro, porque o português saiu para ir para a Índia. Mas ele perdeu a pista e veio bater aqui nas terras tropicais de Pindorama, viu os transeuntes na praia e acabou carimbando de índios. Aquele carimbo errado, equívoco, ficou valendo para o resto das nossas relações até hoje, e a resposta para uma pergunta tão direta e simples poderia ser tão direta e simples quanto. Quando foi que eu atinei que eu tinha de fazer essas coisas que ando fazendo nos últimos 50 anos da minha vida, que é quase que repetir o mesmo mantra, dizendo para esse outro: "ô, cara, essa figura que você está vendo no espelho não sou eu não, é você, esse espelhinho que você está me vendendo não sou eu, isso é um equívoco!"? E saí do sentimento para a prática na pista dos meus parentes mais velhos do que eu, que estavam sendo despachados da zona rural para as periferias miseráveis do Brasil, o que acontece em qualquer canto, no Norte, no Sul, em qualquer lugar. ${ }^{13}$

O ativismo, a militância e o engajamento dos intelectuais e dos escritores indígenas, nesse sentido, têm por base alguns pontos fundamentais: (a) denunciar público-politicamente a condição de exclusão, de marginalização e de violência vividas e sofridas; (b) buscar a demarcação de terras, a valorização dos símbolos, dos códigos, das práticas e dos saberes ancestrais; (c) estabelecer o seu reconhecimento em termos de cidadania política e de singularidade étnico-cultural; (d) desconstruir preconceitos, caricaturas e sentidos negativos produzidos e sustentados na sociedade brasileira contra os povos indígenas em particular, e contras as minorias político-culturais de um modo geral; e, em tudo isso, (e)

13 Cf., ainda: Kopenawa; Albert (2015, pp. 65-66). 
consolida uma práxis político-educacional em que os próprios indígenas, vinculados pública, política e culturalmente, possam contribuir para o crescimento da sociedade. Crescimento esse, diga-se, que exige, entre outras coisas, essa reconstrução da imagem dos povos tradicionais, e, ao promover esse redirecionamento do olhar acerca deles, dar-se-á também uma reelaboração de nossa história e da compreensão que temos acerca de nós mesmos, para a formulação de uma perspectiva crítica e criativa em termos de desenvolvimento e de inclusão socioeconômica.

O Brasil moderno, o Brasil de nosso presente e para nosso futuro necessita enfrentar essa chaga do colonialismo, que permanece em latência teoricamente - uma vez que continua intocado em termos políticos - e que, exatamente por isso, reproduz social, cultural, política e epistemologicamente as segmentações, as exclusões, os silenciamentos, as invisibilizações, as violências e as misérias cotidianas contra nossas minorias, contra a população em geral. Afinal, a exclusão, a marginalização e a violência contra os povos indígenas são também impostas, ainda que de modo diferenciado em muitas situações, a outros extratos sociais, como negros, LGBTTs, mulheres, trabalhadores e aos pobres de um modo geral, o que significa mostrar o quanto a suposta modernização por que o país passou desde a colonização é, ainda, conservadora, marcada por uma perspectiva colonialista profundamente autoritária, racista, violenta e desigual, mantendo essas populações em estado de precarização. Daí a importância do ativismo das minorias de um modo geral e dos povos indígenas em particular, na esfera público-política, para possibilitar seja o enquadramento de nossas instituições, de nossos sujeitos sociopolíticos, de nossos processos de socialização e de subjetivação, seja a reconstrução de nossa história, o repensar de nosso presente e a programação de um futuro mais democrático, igualitário e justo.

Trata-se de pontos fundamentais em termos da transformação social que os povos indígenas, assim como as demais minorias, podem promover, para desconstruir e construir, criticar e fundar-dinamizar, pensar e repensar, afinal sua experiência da colonização e da negação lhes é tão fundamental quanto sua singularidade étnico-antropológica. E a questão mais básica e premente é a de que os povos indígenas são contemporâneos, cidadãos e cidadãs. Esse protagonismo público, político e cultural dos indígenas, via voz-práxis estético-literária, constitui-se em baluarte para o fortalecimento da diversidade, das diferenças, da pluralidade em geral. E, como todos sabemos, o respeito à diversidade exige uma nova história, um 
novo olhar, uma nova perspectiva e um novo caminho em termos sociais, culturais, políticos, institucionais e epistemológicos - novo no sentido de que já não pode mais ser unidimensional, totalizante e massificado, de que já não pode mais ser naturalizado, a-histórico e apolítico-despolitizado, acrítico.

A literatura indígena, nesse sentido, mostra que a crítica social, a resistência cultural, a luta política e a práxis pedagógica são fundadas, viabilizadas e dinamizadas pelo relato autobiográfico, mnemônico e testemunhal das vítimas; em verdade, ela mostra que é por meio da voz-práxis estético-literária que as vítimas superam sua invisibilização, seu silenciamento e seu privatismo, vinculando-se radicalmente na esfera público-política, como sujeitos diretamente politizados e politizantes.

\section{LITERATURA INDÍGENA BRASILEIRA: MOTIVOS, QUESTÕES EPISTEMOLÓGICAS, ESPECIFICIDADE TEÓRICA E RELAÇÃO COM A MODERNIDADE}

Neste tópico, a partir do estudo de algumas obras literárias produzidas pelos/as escritores/as indígenas e levando-se em conta essa correlação de Movimento Indígena e literatura indígena brasileiros acima definida, queremos refletir (a) sobre quatro características (que consideramos) fundamentais apresentadas por tais trabalhos, a saber, a imbricação entre tradição ancestral, comunitária e xamânica com e como crítica do presente (a valorização e a afirmação da tradição e, depois, uma postura de crítica social, de resistência cultural, de luta política e de práxis pedagógica frente à nossa modernização conservadora), por meio da constituição daquilo que estamos chamando de "eu-nós lírico-político", que correlaciona de modo inextricável história coletiva e destino pessoal, numa perspectiva de ativismo, militância e engajamento na esfera pública, política e cultural; a partir disso, (b) uma tematização acerca da classificação teórico-epistemológica e estético-literária das produções artísticas indígenas, ressaltando-se, aqui, o sentido e a especificidade dessa literatura indígena aqui apresentada, inclusive buscando-se refletir sobre a correlação entre a singularidade étnico-antropológica base da constituição e da formulação dessa literatura e a inserção dela - e, de modo anterior, dos próprios povos indígenas - dentro do contexto da cultura europeia moderna que nos serve como bojo antropológico, societal, institucional e epistemológico, 
reflexo da inserção dos próprios povos indígenas (como de resto por parte de cada um de nós e dos diferentes grupos sociais) dentro do horizonte da modernização; e, por fim, (c) uma reflexão sobre essa experiência de intersecção entre cultura indígena e cultura nacional, entre epistemologias indígenas e uma perspectiva epistêmico-política propriamente moderna, por assim dizer, que é assumida seja em termos do ativismo, da militância e do engajamento dos(as) escritores(as) e dos(as) intelectuais indígenas, seja no que tange às experiências interculturais de contato e, em consequência, aqui, à questão da tradução e da fusão recíprocas dessas axiologias (incluindo-se a moderna) em termos desse contato.

Essas são reflexões um tanto genéricas para o momento, mas que, de todo modo, podem situar-nos na recepção das obras estético-literárias indígenas, na compreensão mínima de seu estilo literário e de seu sentido, bem como de sua vinculação política tanto ao Movimento Indígena quanto ao ativismo, à militância e ao engajamento na esfera pública, política e cultural, para não se falar também no seu significado poderosamente contracanônico e anti-institucionalista.

Como a literatura indígena parte da correlação inextricável entre história coletiva e destino pessoal - o que acontece também com a literatura de minorias -, o(a) escritor(a) indígena de antemão está comprometido(a) em publicizar a singularidade étnico-antropológica de seu povo de origem ou em utilizá-la como base para a produção estética que quer apresentar ao público em geral, indígena e não indígena. No mesmo diapasão, ao publicizar essa singularidade étnico-antropológica, o(a) escritor(a) indígena, como já dissemos na primeira parte deste texto, conta da situação de exclusão, de marginalização e de violência vividas e sofridas por seu povo, por causa de sua condição como indígena, como minoria produzida politicamente Com esse movimento, rompe-se aqui com duas escolhas fundantes da perspectiva epistemológico-estética moderna, a saber, de um lado, a noção disso que chamaremos de uma individualidade forte, como que absoluta, que de um modo geral está desligada e sobreposta ao contexto em que está inserida, flanando por cima da história e do grupo de que faz parte e assumindo-se como independente em relação a ele, conforme podemos perceber em definição clássica de Walter Benjamin (1987, p. 59) sobre a autoria literária moderna:

Podemos fazer uma travessia marítima e cruzar o oceano, sem terra à vista, vendo unicamente o céu e o mar. É o que faz o romancista. Ele é o mudo, o solitário. [...] O romancista se separou do povo e do que ele faz. A matriz do romance é 
o indivíduo em sua solidão, o homem que não pode mais falar exemplarmente sobre suas preocupações, a quem ninguém pode dar conselhos, e que não sabe dar conselhos a ninguém. Escrever um romance significa descrever a existência humana, levando o incomensurável ao paroxismo.

De outro lado, rompe-se com o formalismo, a imparcialidade e a neutralidade metodológico-axiológica próprios ao paradigma normativo da modernidade em sua correlação de institucionalismo, cientificismo e tecnicismo como condição da construção e da publicização do conhecimento e da ação socialmente válidos, vinculantes. Na literatura de minorias de um modo geral e na literatura indígena em particular, a intersecção de comunidade-grupo e indivíduo salta para primeiro plano, dinamiza e direciona a construção da obra-práxis em questão, que se torna, por conseguinte, um exercício catártico e altamente político-politizante, comprometido e engajado, em que o(a) escritor(a), ao contar sua biografia, apresenta também a história e o caminho do seu próprio povo, uma vez que, no caso das minorias, a história de vida é a história da própria pertença étnico-antropológica, o eu é o grupo, o grupo é o eu.

Não se entenda essa proposição como anulação da identidade pessoal, mas exatamente no sentido de que a identidade pessoal é, de modo fundamental, étnico-antropológica para si e para os outros, a própria história étnico-antropológica; o sujeito pertencente à minoria como sendo perpassado - para si e para os outros - por essa diferença que o constitui e o legitima/deslegitima (em termos da colonização), como sendo moldado por essa "chaga" que lhe foi imposta em razão de sua pertença. Nesse sentido, a obra-práxis do(a) escritor(a) de minorias é uma catarse de si e para si dessa sua condição de existência social, com vistas à superação do silenciamento, da invisibilização e do privatismo que foram impostos a seu povo, com a consequente politização do contexto em que está inserido(a), das relações que perpassam a construção e a legitimação das minorias como negativas normativamente falando.

E essa voz-práxis estético-literária catártica, ao reconstruir a história de vida enquanto caminho do grupo, torna-se, como já dissemos, uma perspectiva altamente político-politizante, em que o próprio grupo ganha destaque, centralidade, pungência na voz do(a) escritor(a). É nesse sentido que podemos ler a seguinte passagem do livro Metade cara, metade máscara, de Eliane Potiguara (2004, pp. 102-103):

Nosso ancestral dizia:

Temos vida longa! 


\author{
Mas caio da vida e da morte \\ E range o armamento contra nós. \\ Mas enquanto eu tiver o coração aceso \\ Não morre a indígena em mim \\ E nem tampouco o compromisso que assumi \\ Perante os mortos \\ De caminhar com minha gente passo a passo \\ E firme, em direção ao sol. \\ Sou uma agulha que ferve no meio do palheiro \\ Carrego o peso da família espoliada \\ Desacreditada, humilhada \\ Sem forma, sem brilho, sem fama.
}

Por meio da afirmação de que carrega o peso da violência, da exclusão e da marginalização contra seu povo, enquanto minoria que é, a voz-práxis fala com base em sua pertença, uma pertença que quer publicizar-se: ela é mulher indígena da etnia Potiguara, faz parte do horizonte antropológico constituído pelos povos indígenas brasileiros, condição esta que não pode (e não deve) ser escondida nem apagada, que pretende ser reconhecida pela visualização de sua pessoa, pela escuta de seu nome e, como é o caso aqui, pela apreciação de sua escrita literária calcada na e dependente da sua pertença, da sua história como coletividade marginalizada.

Perceba-se na mesma dinâmica que, se o(a) escritor(a) de minorias afirma enfaticamente sua pertença étnico-antropológica (ou sexual, ou religiosa etc.), buscando, a partir daí, reconstruir, publicizar e politizar a história de seu grupo, sua reivindicação de outro futuro liga-se a uma prática que, situada no presente, imbrica sua militância à construção de uma nova perspectiva, que pressupõe um "daqui para frente" relativamente à sua comunidade de origem. Ao expressar-se metaforicamente como "uma agulha que ferve no meio do palheiro", ao enfatizar que "carrega o peso da família espoliada”, o(a) escritor(a) de minorias e, em nosso caso, a escritora indígena em comento, assumem uma perspectiva militante, ativista e engajada em que a rememoração da história de seu povo e de si, e a consequente crítica do presente, possuem um norte, um objetivo: uma condição mais justa e digna para si e seu povo, o que também significa uma condição mais justa e digna para toda a sociedade na qual se está inserido.

Eis aqui outra característica fundamental da voz-práxis e da obra-práxis estético-literárias das minorias, pelas minorias, a saber, assim como há uma profunda imbricação e uma inextricável dependência entre história pessoal e história coletiva, grupo e indivíduo, também essa luta 
por justiça para seu povo é uma luta que inevitavelmente deve exigir justiça para a sociedade como um todo, uma vez que, ainda aqui, há uma dependência e uma vinculação profundas entre a sociedade brasileira mais abrangente e a condição dos povos indígenas. Esse aspecto, aliás, sempre foi enfatizado pelas lideranças, pelos(as) intelectuais e escritores(as) indígenas de modo muito claro, pungente e comprometido. De fato, o ser minoria carrega uma "maldição" - que é também uma "benção", uma "vocação" -, algo similar ao que se vê nas estórias de heróis e de heroínas que Hollywood às vezes nos apresenta: para salvar-se, deve também salvar quem lhe mata, quem lhe condena, isto é, no caso dos povos indígenas, para que uma nova história sobre si possa ser construída, para que uma perspectiva de justiça social para si possa ser construída, há que se construir uma nova história da sociedade em que se está inserido, uma perspectiva de justiça social para essa sociedade como um todo. É por isso, de todo modo, que estamos enfatizando que o cerne da voz-práxis estético-literária das minorias de um modo geral e dos povos indígenas em particular é exatamente, como também insistem Álvaro Tukano, Ailton Krenak, Kaká Werá e Daniel Munduruku, a conquista da cidadania política para os(as) marginalizados(as), para os(as) excluídos(as).

A literatura de minorias, a literatura indígena é pertença étnico-antropológica, é história coletiva que embasa e perpassa a trajetória de vida do(a) escritor(a), que lhe orienta na produção estético-literária, no ativismo político-cultural. "Eu sou Kaká Werá Jecupé, um Txukarramãe que percorre o caminho do Sol, de acordo com a pintura do urucum escrita nesse corpo que guarda a história milenar do nosso povo" (WERÁ JECUPÉ, 2002, p. 15). Ou seja, esse Eu - Kaká Werá Jecupé - é um Povo e, ao expor sua história de vida, explicita também - e de modo consequente - a história de vida de seu povo. A voz-práxis estético-literária das minorias se faz como pertença, vinculação, em carnalidade profunda. É, na verdade, a história política das diferenças que, via violência simbólico-material dinamizada, detonada por essa sua diferença relativamente a padrões massificadores e unidimensionais, foram produzidas de modo pungente em termos históricos. Não por acaso, como reconhecia Frantz Fanon (1968), a diferença, a minoria está inextricavelmente ligada à e dependente da violência, posto que foi produzida e é perpassada por ela. Nesse diapasão, a obra-práxis produzida por essa minoria acaba assumindo, como estamos afirmando, uma perspectiva catártica para si (o grupo e o indivíduo de minorias) e para a sociedade em que está situado. 
Quando eu era música entonada na barriga da mãe, a nossa aldeia foi atacada. Homens empunhados de pequenos trovões de aço fizeram uma grande tempestade; lançando-se contra nós de todos os lados, fazendo chuva de chamas. Curumin, Cunhã, Tijari, Tieti, Mitã, Menononure, Aymeri, Tuja, Tujá-I; corpos destes nomes ao chão, como um estio fúnebre. Quando a última oca derramou sua última lágrima de fogo e se desfez em cinza, restaram pouco mais de oito parentes, entre eles a anciã Meire Mekrangnotire e a filha Yakamara, que viria a ser a mãe que me semearia ao mundo. (WERÁ JECUPÉ, 2002, p. 22) 14

Note-se, nessa passagem de Oré Awé Roiru'a Ma: todas as vezes que dissemos adeus, de Kaká Werá Jecupé, todo esse arcabouço histórico-normativo que perpassa, já de início, a constituição e a evolução de nossa sociedade, em que a chaga do genocídio/etnocídio contra os povos indígenas e a escravidão negra são um de seus núcleos mais básicos $e$ duradouros. Note-se, no mesmo sentido, que a história de vida de Kaká Werá Jecupé se confunde, primeiro, com a própria condição de exclusão, de marginalização e de violência cometidas contra os povos indígenas e, em segundo lugar, explicita, desvela o caminho de constituição de nossa sociedade como um movimento que, ontem e hoje, foi e é marcado pela violência contra nossos povos originários, simbólica e materialmente falando. Por isso, o relato autobiográfico, testemunhal e mnemônico da sua própria história de vida é também fundamentalmente - e jamais poderá deixar de ser - história de seu povo e, enquanto fecho de abóboda de nossa modernização conservadora, dinâmica central da constituição de nossa sociedade. Ora, é dentro desse contexto que a literatura indígena, conforme vimos nos dois capítulos anteriores, procura publicizar a vozpráxis dos povos indígenas, oferecendo uma história alternativa de nossa sociedade e, assim, buscando um diálogo e uma interação profundos com a população brasileira em geral. A literatura indígena, a luta pelas palavras, como vimos na expressão acima de Tiago Hakiy, é encontro aberto, franco e democrático com a sociedade brasileira sobre a causa e a condição indígenas, mas também sobre nosso próprio futuro como

14 Observe-se também a passagem do livro Tardes de agosto, manhãs de setembro, noites de outubro, de Jaider Esbell (2013, p. 74): "Um dia, os homens dos navios chegaram com suas mentiras, vidas cheias de dores, olhos cheios de ódio, barrigas cheias de fome, sangue cheio de doença, seu pensamento cheio de ideia. Eles chegaram e pensaram que tudo era bicho, que tudo era mato sem serventia. Pisaram na praia como se fosse deserta e atearam o primeiro fogo na floresta. Trouxeram suas garrafas com bebidas perigosas e deram ao nativo, que bebeu e tombou para o lado, entregue ao desconhecido, e nunca mais se livrou disso". 
sociedade, como humanidade. É com essa intenção que, por exemplo, Davi Kopenawa oferece suas palavras escritas em "peles de papel” e inspiradas no xamanismo a Bruce Albert, para que este as leve aos brancos em geral, a fim de que se possa construir uma perspectiva cooperativa renovada destes para com os povos indígenas, em que as tradições indígenas possam efetivamente desempenhar um papel fundamental em termos de crítica e de reformulação do processo de modernização. Ele diz a Bruce Albert e, depois, a todos(as) nós:

Como eu, você ficou mais experiente com a idade. Você desenhou e fixou essas palavras em peles de papel, como pedi. Elas partiram, afastaram-se de mim. Agora desejo que elas se dividam e se espalhem bem longe, para serem realmente ouvidas. Eu lhe ensinei essas coisas para que você as transmita aos seus; aos seus mais anciãos, aos seus pais e sogros, aos seus irmãos e cunhados, às mulheres que você chama de esposas, aos rapazes que irão chamá-lo de sogro. Se lhe perguntarem: "Como você aprendeu essas coisas?", você responderá: "Morei muito tempo nas casas dos Yanomami, comendo sua comida. Foi assim que, aos poucos, sua língua pegou em mim. Então, eles me confiaram suas palavras, porque lhes dói o fato de os brancos serem tão ignorantes a seu respeito".

Os brancos não pensam muito adiante no futuro. Sempre estão preocupados demais com as coisas do momento. É por isso que eu gostaria que eles ouvissem minhas palavras através dos desenhos que você fez delas; para que penetrem em suas mentes. Gostaria que, após tê-las compreendido, dissessem a si mesmos: "Os Yanomami são gente diferente de nós e, no entanto, suas palavras são retas e claras. Agora entendemos o que eles pensam. São palavras verdadeiras! A floresta deles é bela e silenciosa. Eles ali foram criados e vivem sem preocupação desde o primeiro tempo. O pensamento deles segue caminhos outros que o da mercadoria. Eles querem viver como lhes apraz. Seu costume é diferente. Não têm peles de imagens, mas conhecem os espíritos xapiri e seus cantos. Querem defender sua terra porque desejam continuar vivendo nela como antigamente. Assim seja! Se eles não a protegerem, seus filhos não terão lugar para viver felizes. Vão pensar que a seus pais de fato faltava inteligência, já que só terão deixado para eles uma terra nua e queimada, impregnada de fumaças de epidemia e cortada por rios de águas sujas!".

Gostaria que os brancos parassem de pensar que a nossa floresta é morta e que ela foi posta lá à toa. Quero fazê-los escutar a voz dos xapiri, que ali brincam sem parar, dançando sobre seus espelhos resplandecentes. Quem sabe assim eles queiram defendê-la conosco? Quero também que os filhos e filhas deles entendam nossas palavras e fiquem amigos dos nossos, para que não cresçam na ignorância. Porque, se a floresta for completamente devastada, nunca mais vai nascer outra. Descendo desses habitantes da terra das nascentes dos rios, filhos e genros de Omama. São as palavras dele, e as dos xapiri, surgidas no tempo do sonho, que desejo oferecer aqui aos brancos. Nossos antepassados as possuíam desde o primeiro tempo. Depois, quando chegou a minha vez de me tornar xamã, a imagem de Omama as colocou em meu peito. Desde então, meu 
pensamento vai de uma para outra, em todas as direções; elas aumentam em mim sem fim. Assim é. Meu único professor foi Omama. São as palavras dele, vindas dos meus maiores, que me tornaram mais inteligente. Minhas palavras não têm outra origem. As dos brancos são bem diferentes. Eles são engenhosos, é verdade, mas carecem muito de sabedoria. (KOPENAWA; ALBERT, 2015, pp. $64-65)$

Perceba-se, nessa passagem de Davi Kopenawa e Bruce Albert, assim como nas passagens mais acima, de Tiago Hakiy, Eliane Potiguara e Kaká Werá Jecupé, as quatro características que, como já dissemos, consideramos fundamentais em termos de constituição, definição e vinculação pública, política e cultural da literatura indígena: essa imbricação profunda entre comunidade e indivíduo, história coletiva e destinação pessoal; o consequente eu-nós lírico-político, em que o(a) escritor(a) indígena fala em nome da sua comunidade, a partir dela, em termos de uma relação autobiográfica, testemunhal e mnemônica que funde coletividade e individualidade em um todo orgânico e mutuamente dependente; a entabulação de uma voz-práxis que, via literatura, assume um sentido altamente político-politizante, carnal e vinculado; o que leva ao ativismo, à militância e ao engajamento público, político e cultural por meio da palavra que se faz pública, que se torna política, conforme esses(as) intelectuais enfatizam permanentemente como mote de sua literatura e de sua vinculação ao Movimento Indígena.

Assim, a passagem acima, d'A queda do céu: palavras de um xamã yanomami, de Davi Kopenawa e Bruce Albert, é, fundamentalmente, um exercício de publicização do que se é, em que se utiliza a tradição ancestral, comunitária e xamânica como forma de autocompreensão, de diálogo intercultural, de crítica social, de luta política. Aqui, a vítima dáse a conhecer em sua singularidade étnico-antropológica para, por meio da exposição de sua história de vida, por meio do relato de seu lugar e de sua situação dentro de nosso processo de modernização conservadora, enquadrar e fundar uma crítica à modernidade, tendo por escopo sua correção e moderação, tarefa que exige a voz-práxis de suas vítimas, e não apenas a perspectiva tecnocrática e racista das elites neocoloniais - como de resto acontece com a democracia enquanto horizontalidade política, normativa e institucional.

Dessa forma, essa voz se torna esfera pública, ativismo, militância e engajamento político-culturais, que superam o silenciamento, a invisibilização e o privatismo aos quais foram empurrados ao longo da constituição e da evolução de nossa sociedade. Ela se torna afirmação do 
arcabouço cultural dos povos indígenas, ao mesmo tempo em que reconto da história de nossa sociedade, denúncia do processo de etnocídio-genocídio em curso contra as minorias. Em tudo isso, ela se abre e se apresenta ao diálogo, em um exercício democrático de cidadania política via posicionamento estético. "Espalhe nossas palavras, assim como em outros cantos parentes da antiga linguagem estão semeando, pela luta, o ato da vida", diz o pajé guarani Tiramãe Tujá para Kaká Werá Jecupé (2002, p. 93), ao iniciar-lhe nos ritos xamânicos guaranis. Espalhar palavras, valores e práticas, difundir histórias alternativas - eis o núcleo, o caminho e o mote da literatura indígena. "Minha cabeça troveja lembranças" (p. 23), lembranças que, uma vez publicizadas, fundam raízes cidadãs e preparam e fortalecem o caminho da democracia, da inclusão, da participação social. Elas possibilitam vozes plurais, perspectivas dissonantes, fazendo saltarem as contradições e, assim, politizando o contexto social, cultural, político e institucional no qual estamos inseridos - pondo em xeque e desconstruindo velhas imagens que despolitizam o pouco de política que ainda temos -. "Meu desejo, ao contar para vocês um pouco de minha vida na aldeia, com todo prazer e emoção que guardo dentro de mim, foi tentar mostrar que as diferenças entre nós devem ser vistas como enriquecedoras, e não como algo que afasta ou assusta" (KATY, 2005, p. 59).

Ora, ao lado dessa perspectiva ativista e militante da literatura indígena brasileira, essa literatura também implica a problematização seja de sua inserção em modelos ou formas tradicionais de literatura ocidental; seja da perspectiva canônica, epistemológica e paradigmática a partir da qual ela se constitui e se enraiza em termos estético-culturais; seja, por fim, da própria relação que as línguas e culturas indígenas estabelecem, no fazer artístico-literário e em sua divulgação nas comunidades indígenas, e mais além, com outras linguagens, como o português, o espanhol, o inglês, o alemão, o francês etc.

Isso nos instiga, inclusive, a falarmos sobre a interculturalidade presente na e dinamizada por essas obras, uma vez que, como dissemos ao longo do texto, a intenção desses(as) escritores(as) indígenas é exatamente dialogar com a sociedade brasileira e com a comunidade internacional sobre a situação dos povos indígenas brasileiros, o que lhes permite associar-se de modo profundo ao Movimento Indígena brasileiro. A partir de agora, tendo por base os dados desenvolvidos acima, buscaremos refletir sobre isso. 
A literatura indígena brasileira, na contemporaneidade, emerge publicamente para a sociedade não indígena com o advento da edição e publicação das obras manufaturadas em caráter coletivo, fruto da educação escolar indígena nas aldeias, ou em caráter individual, a partir da década de 1990,15 por iniciativa de escritores(as) que assumem a pertença, a causa e a condição indígenas como mote para a produção artístico-cultural e sua vinculação à sociedade civil de um modo mais geral (vimos isso pelas passagens de Daniel Munduruku e Kaká Werá, na segunda seção deste texto). Essa publicização traz consigo um arcabouço teórico e literário cujo material reivindica uma recepção específica e diferenciada, isto é, é necessário olhar a literatura indígena desde sua própria matriz, que, exatamente por ser extraocidental, suscita debates acerca do entrecruzamento e do diálogo entre as raízes indígenas e o modelo epistemológico, institucional, literário e político ocidental, inclusive dos fundamentos normativos que permitem delimitar sua especificidade e sua relação para com a modernidade. A literatura, para começo de conversa, passa a ser uma ferramenta de autoafirmação e autovalorização dos(as) autores(as) indígenas e, antes disso, de promoção dos próprios povos indígenas no cenário nacional, como nos diz Daniel Munduruku (2017, p. 122, grifos nossos):

\begin{abstract}
Sim. A literatura passou a ser um instrumento de atualização da Memória, que sempre utilizou a oralidade como equipamento preferencial para a transmissão dos saberes tradicionais. Na compreensão que temos desenvolvido, esse instrumento engloba muito mais que o texto escrito; ele abrange diversas manifestações culturais, como a dança, o canto, o grafismo, as preces e as narrativas tradicionais. Cada uma dessas composições amarra o passado ao presente, estabelecendo uma relação nova com o momento atual, uma relação necessária e urgente para que as culturas possam criar novas soluções para os problemas que pululam cotidianamente.
\end{abstract}

Para além do texto escrito alfabético, aquisição recente das comunidades e sujeitos tradicionais, reitera Daniel, a literatura pode ser "falada, dançada, cantada" (MUNDURUKU, 2017, p. 122), embora ele se valha predominantemente da literatura escrita e de sua veiculação específica para informar a sociedade brasileira sobre sua diversidade cultural e linguística. Apesar de serem de sociedades fundamentalmente

15 A primeira obra literária individual brasileira escrita por um indígena é Oré Awé Roiru'a Ma: todas as vezes que dissemos adeus, de Kaká Werá Jecupé, publicada no ano de 1994 pela editora Triom. 
orais, as comunidades indígenas passaram a adotar a escrita alfabética e o impresso como forma de dialogar com e educar a sociedade não indígena. Ora adotam publicações cuja língua materna não vem seguida de tradução para a língua portuguesa, ora adotam a escrita em línguas europeias. No primeiro caso, argumenta Thiél (2012, p. 43), expressar-se somente em língua nativa pode constituir diferentes estratégias de resistência no sentido de que se utiliza desse recurso com fins próprios aos interesses da comunidade ou do(a) escritor(a) individual, em todo caso, a fim de dinamizar sua língua materna:

1) pode ser uma forma de assegurar visibilidade às comunidades indígenas: assim se desfaz a noção de unidade linguística nacional, que ainda hoje é defendida pelos centros de poder; 2) pode vir a legitimar autonomia identitária e política; 3) pode ser uma estratégia de resistência cultural, linguística e de autodeterminação; 4) deve-se também à necessidade de manter uma ligação com a sabedoria ancestral pelo discurso; 5) pode corresponder a um recurso pedagógico que conduz ao aprendizado das línguas/cosmovisões nativas em escolas indígenas com material da própria comunidade; finalmente, 6) pode constituir recurso poético de criação e valorização da palavra ancestral, da sonoridade, do ritmo e da performance das comunidades nativas.

Por sua vez, no segundo caso, a utilização da escrita em língua portuguesa e, além disso, em línguas europeias para dinamizar suas literaturas, ${ }^{16}$ pode ser vista, conforme elenca a autora, (a) como estratégia de comunicação, percepção que também é compartilhada por Daniel Munduruku, em passagem citada acima; (b) como divulgação no espaço de poder, conforme expõe Davi Kopenawa em A queda do céu; e, ainda, (c) "como saída da produção indígena de uma situação de marginalidade" (THIÉL, 2012, p. 43), como superação de sua invisibilização, de seu privatismo, de seu silenciamento, como também reflete Olívio Jekupé (2009), em sua obra intitulada Literatura escrita pelos povos indígenas. Dessa forma, é possível perceber que a interlocução entre as matrizes indígenas e o ocidente tem representado, para a teoria literária indígena, tanto um lugar de autoafirmação e valorização quanto um campo e um instrumento de crítica e resistência às epistemologias modernas, uma vez

16 Como exemplo, podemos citar as obras de Daniel Munduruku, algumas das quais foram traduzidas e publicadas em outros idiomas: El niño y el gorrión (2008), publicado no México pela editora Secretaría de Educación Pública; Indianerlegenden aus Brasilien (2015), pela editora Hans Schiler na Aústria, em idioma alemão; Tales of the Amazon (2000), pela editora Grooundwood Books, em inglês, nos Estados Unidos e Canadá; Cose de índio (2012), pela Callis/Instituo Callis, em italiano, na Itália. 
que estas não se concentram em perceber o lugar de fala (DALCASTAGNÈ, 2012) desse grupo constituído enquanto minoria periferizada em termos de modernização. Para Daniel Munduruku (2017, p. 132), pensar a literatura indígena consiste em tematizá-la "em movimento de transição em que oralidade e literatura criaram uma simbiose tamanha incapaz de haver separação ou anulação de uma pela outra”, de modo que, ainda segundo Daniel Munduruku, a literatura (escrita) não apaga a oralidade ou vice-versa.

A emergência dessa literatura é tamanha que já conta com quarenta autores(as) atuantes, de acordo com Daniel Munduruku (2017). Diante dessa quantidade de autores é possível imaginar a pluralidade de temas que constituem tais obras. Apesar dessa pluralidade, destacamos que a autoria indígena, que se divide em coletiva e individual (cf.: ALMEIDA; QUEIROZ, 2004; GRAÚNA, 2013; MUNDURUKU, 2017), tem sempre como mote a ancestralidade, a valorização da tradição e a crítica do presente. Para Graúna (2013, p. 172), "a noção de coletivo não está dissociada do livro individual de autoria indígena; nunca esteve, muito menos agora com a força do pensamento indígena configurando diferenciadas(os) estantes e instantes da palavra". Assim, encontramos, nos contos, nos poemas, nas (auto)biografias, nas memórias indígenas, a ancestralidade reestilizada de modo criativo. A seguir, explicitamos alguns trechos de obras dos(as) escritores(as) indígenas que afirmam o orgulho pela ancestralidade, valorizando a tradição no reconto das histórias sagradas ou cotidianas à sociedade não indígena. Na passagem a seguir, de Edson Krenak (2011, p. 7), no livro $O$ sonho de Borum, vemos a introdução ao universo deste escritor a partir da sua experiência onírica:

Todas as noites de inverno, nos reunimos no centro comunitário da aldeia para ouvirmos as lindas histórias dos mais velhos. Gosto muito das histórias do cacique e das narrativas encantadas do pajé. Eles contam histórias dos ancestrais, das guerras, das aventuras no meio da floresta, das grandes caçadas, que hoje estão tão pequenas [...] Eu adoro quando falam dos encontros com a onça pintada na mata virgem, ou com a jaguatirica e o tamanduá-bandeira às margens do grande e furioso Rio Doce.

Mas um dia fiquei com um tremendo frio na barriga. O pajé, ao terminar sua história naquela noite fria, olhou firmemente para mim e disse:

- Amanhã, Cruquerré, você vai nos contar um sonho! 
A tradição ancestral, nas palavras de Edson Krenak, ritualizada na reunião da comunidade que se junta para ouvir as histórias antigas que configuram a cosmologia do povo Krenak, é trazida para os não índios, dando a conhecer o seu mundo, os grandes eventos - guerras e aventuras -, mas sem esquecer-se da ação colonizadora do homem "branco" sobre a floresta. Desse modo, denunciam metalinguisticamente na narrativa os problemas do contato do não indígena com a natureza e de sua compreensão sobre ela; não se tem mais grandes caçadas, porque há menos caça e menos grupos indígenas em consequência da colonização sobre os territórios indígenas. Katy Sulamy (2011), em sua obra Nós somos só filhos, também evoca pela ancestralidade o orgulho da pertença étnica, a valorização da tradição e a denúncia metalinguística da visão do homem sobre a natureza, promovida sob a forma de nossa modernização conservadora:

Nós somos filhos da água, da mata e do entardecer. Vemos a vida com a visão dos que nascem no meio das pedras tendo a palha do ouricuri como ninho que, para ser visto, tem que ser tingido de negro e, dessa forma, nossa gente obtém o direito de pertencer. $\mathrm{O}$ sangue de nossos antepassados adubou nossa terra, fez nascer o urucum que, quando é pintado em nosso corpo, deixa nosso espírito livre para voar sobre a terra encantada, dançar ao redor da fogueira sagrada das festas do nosso povo que, com um sorriso de prata, ilumina a mata inteira e nos traz o amanhecer. Nós somos filhos do fogo! E sabemos que o melhor de tudo isso é que NÓS SOMOS SÓ FILHOS!

Em ambas as passagens, de Edson Krenak e de Katy Sulamy, vemos sujeitos que não estão descontextualizados de suas tradições. A voz enunciativa evoca a tradição ancestral como essencial à alteridade desses sujeitos. Por meio do livro, ambos os autores reforçam sua pertença étnica, o orgulho de ser parte de um povo, dos costumes, o respeito aos rituais e a compreensão de que fazem parte dessa terra como filhos, como integrados à floresta, em uma relação de simbiose. Aqui, o eu-nós se apresenta em prosa, e em prosa poética na segunda passagem, denotando a compreensão que possuem de sua identidade, isto é, são sujeitos individuais com crenças, valores e costumes norteados pela comunidade de que descendem. E é uma produção lírico-política porque, via literatura, denuncia metalinguisticamente a violência histórica sobre si, sobre suas cosmovisões violentadas pelo não indígena e em termos de modernização conservadora. Se Krenak postula que não há mais caçadas como antigamente, Sulamy reconhece que os povos indígenas não são donos das florestas, mas filhos dela. Daí inferimos que há crítica do presente nos 
textos literários dos autores indígenas na contemporaneidade, justamente porque eles partem de sua singularidade antropológica para desnudar sua condição, sua situação, que se situa historicamente na violação de seus direitos. Apesar desse fato histórico, os escritores utilizam-se das narrativas para celebrar a vida indígena em suas especificidades, denunciando, ora implícita, ora explicitamente, a violência que os persegue, seja física ou epistemologicamente.

O adentramento na via literária caracteriza-se, por isso mesmo, pelo ativismo e pela militância em defesa dos saberes, da revisão da História oficial e do direito de ser cidadão, e de não se considerado um estrangeiro no próprio país, como censura Kaká Werá (2002), em seu texto literário Todas as vezes que dissemos adeus. Na passagem a seguir de René Kithãulu (2002, p. 7), vemos o porquê de o engajamento desde si mesmo ser uma prioridade para esses sujeitos indígenas:

\footnotetext{
Sabe, existem livros que ensinam coisas verdadeiras sobre os povos indígenas, mas há também aqueles que não mostram as coisas como elas são. Por isso, vocês podem pensar que todos os índios do Brasil são iguais, falam a mesma língua e moram em ocas. No nosso país existem mais de 18o línguas indígenas. Meu povo, por exemplo, só fala a língua Nambikwara, e somos várias etnias diferentes. Quando vocês veem uma casa indígena, chamam sempre de "oca". Mas essa é uma palavra tupi. Os Nambikwara chamam de sixsu. E quem dança fazendo aquele "uh, uh, uh" com a mão na boca são nossos parentes índios da América do Norte. Como vocês veem, há muitas diferenças...
}

Como podemos perceber, a autovalorização e a autoafirmação por meio da pertença étnico-antropológica e de sua consequente tradição cultural, com seu aparecimento, via voz-práxis estético-literária, podem servir de suporte para desnudar equívocos perpetrados contra os povos tradicionais. Assim, René Khitãulu reforça que a ausência da enunciação desde si mesmo colabora para a mistificação dos povos indígenas em uma massa homogênea e sem diferenciação interna, uma massa homogênea que, ademais, ficou estilizada como um silvícola do passado pura e simplesmente, como se os próprios povos indígenas não tivessem se atualizado, não tivessem evoluído juntamente com a sociedade brasileira de um modo mais geral, justamente com nossa modernização conservadora e à revelia dela. Tal enquadramento nega a complexidade cultural desses povos, ignorando a riqueza de suas tradições específicas, da configuração de suas sociedades, da militância em defesa de suas ancestralidades, de cada pertença étnica que não se encerra sob o nome de "tribo" ou de "índio". No mesmo diapasão, essa estilização acrítica 
dos povos indígenas deslegitima-os como seres do presente, como cidadãos(ãs) e grupos sociais capazes de cidadania política e igualmente sujeitos democráticos, como todos(as) nós - afinal de contas, quem ficou no passado não é interlocutor da situação presente -. Daí a literatura indígena consolidar, com autores como Kaká Werá e Daniel Munduruku, a figura dos(as) indígenas intelectuais, ativos(as) na esfera pública, política e cultural, que desconstroem enfaticamente as caricaturas feitas sobre os povos indígenas por meio da própria produção estética, literária e política.

Dessa forma, como já dissemos, a experiência intercultural, o entrecruzamentodo mundo oral com oda escritaalfabética, tem desenhado um panorama da literatura indígena brasileira na contemporaneidade em que esses mesmos povos indígenas, seus(as) escritores(as) e intelectuais se apropriam das linguagens eruditas e das ferramentas digitais, ligadas à editoração, para promover seus próprios códigos e, no caso, para entabular uma perspectiva de ativismo político-cultural na sociedade brasileira mais ampla. Os próprios sujeitos indígenas conceituam o que eles compreendem como literatura, como vimos acima em Daniel Munduruku, reiterando que a realização da sua expressão é adveniente da luta dos grupos em defesa dos direitos dos índios na década de 1970, no Movimento Indígena. Podemos ler as demais expressões publicadas a partir da década de 2000 em razão do grande desdobramento dessa luta política forjada no cenário brasileiro e que consolidou os povos indígenas, seus(uas) intelectuais e escritores(as) em termos públicos, políticos e culturais, inclusive acadêmicos, em muitas situações.

A luta que a literatura tem trazido abrange outra dimensão, ainda in progress, que é a da compilação e da publicização dos mitos de origem, das tradições culturais fundadoras de cada povo indígena. Mas, é perfeitamente possível afirmar, aqui, que a ancestralidade utilizada como matéria para a expressão desses escritores não subverte nem anula seu caráter sagrado. Para Graúna (2013, p. 172), portanto,

Ao tomar o rumo da escrita no formato de livro, os mitos de origem não perdem a função, nem o sentido, pois continuam sendo transmitidos de geração em geração, em variados caminhos: no porantim, no traçado das esteiras e dos cestos, na feitura do barro, na pintura corporal, nas contas de um colar, na poesia, na contação de histórias e outros fazeres identitários que os Filhos e as Filhas da Terra utilizam como legítimas expressões artísticas, ligando-as também ao sagrado. 
De todo modo, isso vale para a literatura indígena brasileira de um modo geral: por um lado, as histórias que ela apresenta - tanto em termos da singularidade e da pertença étnico-antropológica de seus(uas) escritores(as) quanto no que se refere à reconstrução e à denúncia da violência cometida em nome da colonização e, depois, de nossa modernização conservadora - perpassam a constituição das próprias comunidades indígenas e dinamizam seus processos de socialização e de subjetivação internos - são as histórias de humanidade, no dizer de Álvaro Tukano (2017), que representam a base normativa para a constituição e a vida cotidiana desses povos indígenas -; por outro lado, a utilização da escrita alfabética, das ferramentas digitais e da impressão gráfica, assim como das inúmeras mídias de um modo geral, aponta para o fato de que os povos indígenas assumem-se como inseridos dentro do contexto de nossa sociedade, mostrando que são - assim como todos nós - atingidos em cheio pelas consequências deletérias do processo de modernização. Nesse aspecto, mais do que um fenômeno próprio à tradução intercultural entre âmbitos a rigor tão díspares como o mundo indígena e a cosmovisão moderna, mais do que uma negação da própria especificidade e uma aceitação, ainda que indireta, da própria perspectiva colonial, a construção da literatura indígena, pelos(as) escritores(as) indígenas, aponta para sua profunda consciência seja da pertença à sociedade brasileira, que lhes é negada muitas e muitas vezes, seja da necessidade de atualização e de exercício permanentes da cidadania política como condição da emancipação de si e da sociedade em que estão inseridos (enquanto movimento recíproco). Ou seja, os(as) indígenas possuem literatura a partir de sua pertença e enquanto singularidade étnico-antropológica porque são, em primeiro lugar, cidadãos e cidadãs dessa imensa mãe Brasil, parte fundamental da história brasileira, mas também de seu presente e de seu futuro.

\section{CONSIDERAÇÕES FINAIS}

Indígenas em movimento perceberam e afirmaram a esfera público-política e a práxis político-cultural como espaço e instrumento para sua autoafirmação, parasua resistênciaepara sualuta;indígenasem movimento afirmaram e utilizaram a literatura como voz-práxis carnal, políticapolitizante e vinculada, em termos de ativismo, militância e engajamento em torno do Movimento Indígena. A literatura indígena, assim, desponta, na contemporaneidade, como espaço político, pedagógico e cultural por 
excelência para a elaboração de um relato testemunhal, mnemônico, autobiográfico e autoral de uma minoria político-cultural produzida via colonialismo, que até então teria estado relegada, em termos de nossa modernização conservadora, ao mais obscuro canto de nosso passado e de nossa história, como pré-civilização, como pré-história, como pré-cidadania. Sem voz e sem vez, essa minoria não pôde, até recentemente, nos contar muito de sua história, de sua versão da colonização, da sua ideia do Brasil, sendo gradativamente submetida a um processo de deslegitimação, de invisibilização, de silenciamento e de extermínio cada vez mais intensificados, a ponto de, como reconheceu Ailton Krenak (2015), os próprios indígenas acreditarem que não sobreviveriam para ver o século XXI chegar.

Sobreviveram e frutificaram, e isso se deve, conforme pensamos, à correlação de Movimento Indígena e politização-publicização dos indígenas como sujeito, causa e condição intersubjetivos da nação brasileira como um todo. Para isso, a literatura indígena contribuiu em cheio; aliás, essa foi sempre a sua intenção, isto é, ela sempre promoveu a publicização, a politização e a institucionalização do sujeito e da questão indígenas no país, seu fomento sociocultural, a consolidação de uma episteme, de uma política e de uma cultura indígenas como instâncias importantes para repensarmos a história, as práticas, os sujeitos, as instituições, as relações e os valores de nosso Brasil. Nela, podemos perceber uma voz-práxis direta, carnal, pungente e vinculada, constituída e dinamizada sob a forma de um relato autoral, testemunhal, mnemônico e autobiográfico em que a singularidade antropológica e a condição de marginalização-exclusão-violência aparecem-nos em cheio, questionando a nossa própria constituição como sociedade-cultura brasileira, o nosso modelo antropológico, societal, cultural e epistemológico de modernidade brasileira. De fato, na correlação de Movimento Indígena e literatura indígena aparece o Brasil dos indígenas, o Brasil contado pelos indígenas e, portanto, surge uma esfera pública, política e cultural mais diversificada, isto é, mais crítica, mais democrática, mais participativa, interligando política, educação e/como literatura de minorias, pelas minorias.

\section{INDIAN IN MOVEMENT, LITERATURE AS ACTIVISM}

Abstract: In this paper, we correlate the public-political emergence and protagonism of Brazilian Indian Movement, since the mid-1970s, with the emergence and consolidation 
of Brazilian Indian literature since 1990s. We will argue that, in the same way that founding Indian leaderships and intellectuals of Indian Movement perceived that only the publicization and politicization of their condition and cause from the streamlining of a direct voice-praxis of the own Indians by themselves and from themselves, with no institutionalist mediations, could unveil and politicize the Indian situation in the country, the Indian literary writers concluded that just by producing their own literary works they could both to deconstruct the caricature, folkloric and negative image made of them in an alien way, and to reorient the looking, to reformulate the comprehension and to recreate the image of these Indians by themselves. In this sense, Brazilian Indian literature links itself directly to the Indian Movement and aims the publicization and politicization of the Indian peoples, constituting itself as an activist, militant and engaged voice-praxis in which the lyrical-political I-We assumes the promotion of the anthropological singularity and of cultural diversity and the denounce of the exclusion, marginalization and violence as its more basic purpose and direction, searching to overcome the invisibilization, the silencing and the privatism to which they were submitted in our society.

Keywords: Indian Movement; Indian Literature; Activism.

\section{REFERENCIAS}

ALMEIDA, Maria Inês de; QUEIROZ, Sônia. Na captura da voz: as edições da narrativa oral no Brasil. Belo Horizonte: Autêntica; FALE/UFMG, 2004.

BANIWA, Gersem dos Santos Luciano. O índio brasileiro: o que você precisa saber sobre os povos indígenas no Brasil de hoje. Brasília: Ministério da Educação, Secretaria de Educação Continuada, Alfabetização e Diversidade; LACED/Museu Nacional, 2006.

BEHR, Heloïse. A emergência de novas vozes brasileiras: uma introdução à literatura indígena no Brasil. In: MELLO, Ana Maria Lisboa de; PENJOM, Jacqueline; BOAVENTURA, Maria Eugenia (orgs.). Momentos da ficção brasileira. Porto Alegre: EDIPUCRS, 2017, pp. 259-279.

BENJAMIN, Walter. Magia e técnica, arte e política. São Paulo: Brasiliense, 1987.

ESBELL, Jaider. Tardes de agosto, manhãs de setembro, noites de outubro. Boa Vista: Edição do Autor, 2013.

FANON, Franz. Os condenados da Terra. Rio de Janeiro: Civilização Brasileira, 1968.

GRAÚNA, Graça. Contrapontos da literatura indígena contemporânea no Brasil. Belo Horizonte: Mazza Edições, 2013.

HAKIY, Tiago. Awyató-Pót: histórias indígenas para crianças. São Paulo: Paulinas, 2011.

JECUPÉ, Kaká Werá. Oré Awé Roiru’a Ma: todas as vezes que dissemos adeus. São Paulo: Triom, 2002.

JEKUPÉ, Olívio. Literatura escrita pelos povos indígenas. São Paulo: Scortecci Editora, 2009. 
Indígenas em movimento. Literatura como ativismo - 958

KATY, Sulami. Meu lugar no mundo. São Paulo: Ática, 2005.

KATY, Sulamy. Nós somos só filhos. Ilustrações Maurício Negro. 1. ed. Rio de Janeiro: ZIT, 2011.

KITHÃUlU, Renê. Irakisu: o menino criador. Ilustrações do autor e das crianças Nambikwara. São Paulo: Peirópolis, 2002.

KOPENAWA, Davi; ALBERT, Bruce. A queda do céu: palavras de um xamã yanomami. Trad. Beatriz Perrone-Moisés. São Paulo: Companhia das Letras, 2015.

KRENAK, Ailton. Encontros. Org. Sergio Cohn. Rio de Janeiro: Azougue Editorial, 2015.

KRENAK, Ailton. Ailton Krenak. Org. Kaká Werá. Rio de Janeiro: Azougue Editorial, 2017. (Coleção Tembetá).

KRENAK, Edson. O sonho de Borum. Ilustrações Mauricio Negro. Belo Horizonte: Autêntica, 2015.

MUNDURUKU, Daniel. O caráter educativo do movimento indígena brasileiro (1970-1990). São Paulo: Paulinas, 2012.

MUNDURUKU, Daniel. Catálogo de obras de Daniel Munduruku - atualizado. São Paulo: DM Projetos Especiais/UK’A Editorial, 2016a.

MUNDURUKU, Daniel. Memórias de índio: uma quase autobiografia. Porto Alegre: EDELBRA, 2016b.

MUNDURUKU, Daniel. Mundurukando II: roda de conversa com educadores. Lorena: UK'A Editorial, 2017.

POTIGUARA, Eliane. Metade cara, metade máscara. São Paulo: Global, 2004.

SÁ, Lúcia. Literaturas da floresta: textos amazônicos e cultura latino-americana. Rio de Janeiro: Eduerj, 2012.

SULAMY, Katy. Nós somos só filhos. Ilustrações Mauricio Negro. Rio de Janeiro: ZIT, 2011.

THIÉL, Janice. Pele silenciosa, pele sonora: a literatura indígena em destaque. Belo Horizonte: Autêntica Editora, 2012.

TUKANO, Álvaro. Álvaro Tukano. Org. Kaká Werá. Rio de Janeiro: Azougue Editorial, 2017. (Coleção Tembetá).

VALENTE, Rubens. Os fuzis e as flechas: história de sangue e resistência indígena na ditadura. São Paulo: Companhia das Letras, 2017.

WERÁ, Kaká. Kaká Werá. Org. Kaká Werá. Rio de Janeiro: Azougue Editorial, 2017. (Coleção Tembetá). 
Remate de Males, Campinas-SP, v.38, n.2, pp. 919-959, jul./dez. 2018 - 959

WERÁ, Kaká. O trovão e o vento: um caminho de evolução pelo xamanismo tupi-guarani. São Paulo: Polar, 2016.

\section{Sites consultados:}

Articulação dos Povos Indígenas Brasil - APIB. Disponível em: <www.apib.info/apib/>. Data de acesso: 26 jul. 2018. 